\title{
El Partido Democrático de Chile: de la guerra civil a la AlianZa Liberal (1891-1899)**
}

\begin{abstract}
RESUMEN
El presente artículo reconstituye y analiza detalladamente el itinerario que llevó al Partido Democrático de Chile (PD) en los últimos años del siglo XIX, al ingresar a la Alianza Liberal e incorporarse de lleno al sistema parlamentarista. Planteamos que el PD tuvo dos motivaciones básicas que se entrelazaron estrechamente y que hicieron indefectible su convergencia con la Alianza Liberal y participación en el juego parlamentarista. Uno ideológico: su anticonservadurismo y anticlericalismo; y uno práctico: la necesidad de "defender" las diputaciones obtenidas en el momento de la calificación de las elecciones por los parlamentarios, lo que los obligaba a buscar aliados. Ambos motivos se desprendían, a la vez, del carácter reformista de este partido, de su autoidentificación con el liberalismo -como su ala plebeya, más decidida y consecuente- $\mathrm{y}$ de su proyecto de reforma democrática del Estado oligárquico.
\end{abstract}

Palabras clave: Partido Democrático de Chile, Alianza Liberal, República Parlamentaria, historia política y social, movimiento obrero.

\section{Abstract}

The present article reconstructs and analyzes in detail the path that the Chilean Democratic Party (PD) took during the final years of the nineteenth century, upon entering the Liberal Alliance and fully participating in the parliamentary system. The article argues that the PD had two basic motivations which were closely interwoven and which made its incorporation into the Liberal Alliance as well as its participation in the parliamentary political game inevitable. One of these motivations was ideological: the parties' anticonservatism and anticlericalism. The other was practical: the necessity to "defend" their congressional seats, which forced them to find allies in the process of certifying the elections by the parliament. At the same time both motives came from the reformist character of the PD, its' self-identification as the plebian side of liberalism (more resolute and consequent) and from its project to democratically reform the oligarchic state.

Key Words: Chilean Democratic Party, Liberal Alliance, Parliamentary Republic, Political and Social History, Workers movement.

Fecha de recepción: marzo de 2012

Fecha de aceptación: septiembre de 2012

* Doctor en Historia, École des Hautes Études en Sciences Sociales de París (E.H.S.S.). Académico de la Universidad de Chile. Correo electrónico: sergiogreztoso@gmail.com

** Artículo elaborado en el marco del proyecto Fondecyt $N^{\circ} 1100047$, financiado por la Comisión Nacional de Investigaciones Científicas y Tecnológicas (Conicyt). 


\section{UN VACÍO HISTORIOGRÁFICO}

Durante mucho tiempo se careció de sólidos estudios acerca del Partido Democrático de Chile (PD). Solo se contaba con el libro del militante demócrata Héctor de Petris Giesen ${ }^{1}$, que, además de su poca profundidad, adolece de varios defectos, entre ellos su carácter apologético, la carencia del savoir faire profesional historiográfico de su autor (jurista) y su perspectiva eminentemente "positivista", sin planteamiento de problemáticas que orienten el relato.

También se conocían algunas generalidades sobre los primeros años del PD, sobre todo gracias al aporte de los historiadores marxistas clásicos chilenos: Julio César Jobet, Marcelo Segall y Hernán Ramírez Necochea², pero estas referencias, además de superficiales, contienen una serie de errores, tal como lo hemos demostrado en algunos trabajos citados más adelante. Entre los historiadores que podrían ser considerados como una segunda generación de la misma escuela historiográfica, cabe destacar a Jorge Barría Serón, quien reconoció el importante papel del PD en la organización de los sindicatos, en la creación de una conciencia social y política popular y en el voto de las primeras leyes sociales. Sin embargo, al considerar "desalentadora" la política demócrata durante la segunda década de la centuria, Barría no encontró más incentivos para estudiar con mayor detención a este partido, del mismo modo como había ocurrido con Ramírez y Segall ${ }^{3}$. Por su parte, Fernando Ortiz Letelier, continuador de Ramírez, tampoco puso más de atención al PD en su tesis escrita en 1956 (publicada como libro en 1985). Aunque incluyó en sus anexos documentales el Programa demócrata de 1889, apenas consagró poco más de dos páginas a dicha colectividad. Al igual que Barría, reconoció su papel precursor en la organización política del pueblo y en el impulso a la legislación social, pero se detuvo luego de entregar un par de antecedentes muy generales, constatando que el progreso alcanzado por el PD "descansaba en éxitos muy precarios: la base artesanal de un sector influyente demócrata, la demagogia de muchos de sus dirigentes y la adhesión sin principios a combinaciones electorales, [que] explicarán, en parte, su posterior descenso"4. Para Ortiz, como para la generalidad de los historiadores "marxistas clásicos" chilenos, el surgimiento del Partido Obrero Socialista (POS) fue el fin lógico para la parte sana del PD, ahorrándose de esta manera mayores estudios posteriores. Más tarde, Luis Vitale, en su Interpretación marxista de la historia de Chile, apenas mencionó unas cuantas veces a este partido o a algún dirigente social perteneciente a

' Héctor de Petris Giesen, Historia del Partido Democrático. Posición dentro de la evolución política nacional, Santiago, Imprenta de la Dirección General de Prisiones, 1942.

2 Julio César Jobet, Recabarren y los orígenes del movimiento obrero y del socialismo chileno, Santiago, PLA, 1955; Marcelo Segall, Desarrollo del capitalismo en Chile. Cinco ensayos dialécticos, Santiago, Editorial del Pacífico, 1953; Hernán Ramírez Necochea, Historia del movimiento obrero en Chile. Antecedentes. Siglo XIX, Santiago, Editorial Universitaria, 1956; y Balmaceda y la contrarrevolución de 1891, Santiago, Editorial Universitaria, 1969.

3 Jorge Barría S., Los movimientos sociales de Chile desde 1910 hasta 1926 (Aspecto político y social), Santiago, Editorial Universitaria, 1960.

${ }^{4}$ Fernando Ortiz Letelier, El movimiento obrero en Chile 1891-1919, Madrid, Ediciones Michay, $1985,260$. 
sus filas ${ }^{5}$. Abreviando el balance referido a este grupo de autores, podemos concluir que, por razones esencialmente ideológicas, el PD quedó virtualmente fuera de sus preocupaciones historiográficas.

Aparte de estos textos, el papel de este partido en algunas coyunturas fue evocado de paso en varios artículos y libros referidos a otras temáticas. Gonzalo Izquierdo mencionó su actuación, especialmente la de su líder Malaquías Concha, en los sucesos de la "huelga de la carne" o "semana roja" de Santiago, en octubre de 19056. Otro tanto hizo Vicente Espinoza ${ }^{7}$, mientras que Crisóstomo Pizarro rememoró -muy de pasada- el papel de los demócratas en algunos conflictos sociales de las primeras décadas del siglo XX, ahondando un poco más en su participación en la Asamblea Obrera de Alimentación Nacional (AOAN), en 1918-1919². En su libro sobre la matanza de la escuela Santa María de Iquique, Eduardo Devés mostró la responsabilidad de la política del PD iquiqueño en la gestación de la "huelga grande" tarapaqueña de 1907 y sus contradicciones con la Sociedad Mancomunal de Obreros". Peter DeShazo también entregó algunos elementos de caracterización general de la política demócrata, tanto en las luchas sociales como en las de tipo electoral, y se refirió, muy concisamente, a la trayectoria histórica de este partido durante las tres primeras décadas del siglo XX, repasando brevemente algunas de sus divisiones y otros hitos importantes ${ }^{10}$.

En términos generales, se puede decir que hasta fines de la década de 1980 era válido sostener, como lo hizo en 1985 Samuel J. Valenzuela, que el PD no había encontrado su historiador y que su significación en el desarrollo del movimiento obrero chileno no había sido valorada suficientemente, debido al trato negativo que había recibido en la literatura especializada, especialmente por parte de Hernán Ramírez Necochea, que lo había identificado mayormente como una expresión de la "pequeña burguesía"ll.

Pero desde entonces los progresos de la historiografía consagrada al PD han sido considerables, tan sustantivos que, a pesar de la subsistencia de numerosas lagunas y zonas oscuras, las afirmaciones de Valenzuela ya no tienen validez. Siguiendo un orden que intenta compatibilizar la aparición cronológica con los temas abordados, el panorama general del nuevo conocimiento puede resumirse como sigue.

5 Luis Vitale, Interpretación marxista de la Historia de Chile. De la República parlamentaria a la República Socialista (1891-1932), vol. IV, Santiago, Lom Ediciones, 1993 [2a edición], 109 y 120-121.

6 Gonzalo Izquierdo F., "Octubre de 1905. Un episodio en la historia social de Chile", Historia 13, Santiago, 1976, 55-96.

7 Vicente Espinoza, Para una historia de los pobres de la ciudad, Santiago, Ediciones Sur, 1988, 24-32.

${ }^{8}$ Crisóstomo Pizarro, La huelga obrera en Chile. 1890-1970, Santiago, Ediciones Sur, 1986.

9 Eduardo Devés, Los que van a morir te saludan. Historia de una masacre: Escuela Santa María de Iquique, 1907, Santiago, Ediciones Documentas, 1989 [3 $3^{\text {a }}$ edición].

${ }_{10}$ Peter DeShazo, Trabajadores urbanos y sindicatos en Chile: 1902-1927, Santiago, Centro de Investigaciones Barros Arana, 2007, 179-185 (edición original: Urban Workers and Labour Unions in Chile, 1902-1927, Madison, Wisconsin University Press, 1983).

11 J. Samuel Valenzuela, Democratización vía reforma: La expansión del sufragio en Chile, Buenos Aires, Ediciones del IDES, 1985, 45. 
Como derivados de nuestra tesis doctoral defendida en $1990^{12}$, en varios trabajos publicados posteriormente realizamos una contribución referida a los primeros años del PD, situando su aparición y desarrollo inicial en el contexto más amplio del movimiento popular de la época. En estos textos, y de manera especial en nuestra principal obra, se reconstituyen detalladamente las primeras fases de la historia del PD, conectándolas con procesos de distinta duración en el seno del movimiento popular decimonónico y refutando, de paso, una serie de inexactitudes contenidas en los libros de Ramírez y Segall ${ }^{13}$. De esta manera, quedaron sentadas las bases para futuras investigaciones sobre el período posterior a 1891.

Desde entonces el conocimiento sobre la historia del PD ha experimentado algunos avances parciales que son dignos de anotar. La región del salitre, especialmente la provincia de Tarapacá, ha sido el objeto privilegiado de estos trabajos. Julio Pinto realizó un aporte significativo respecto de los primeros años del PD en Tarapacá, al destacar las peculiaridades regionales que le imprimieron un desarrollo distinto al de otros puntos del país ${ }^{14}$. Pinto también sondeó los caminos de la politización popular en Tarapacá a fines del siglo XIX, concluyendo que, si bien esta era real -a diferencia de otras regiones del país-, hasta el cambio de siglo fue más el resultado de la acción "desde arriba" - desde los partidos de la élite- que del PD o de los aún debilísimos grupos anarquistas o socialistas ${ }^{15}$. Este mismo autor, en un artículo sobre los orígenes del POS en Tarapacá, entregó antecedentes sobre la evolución en la época del Centenario de una importante fracción demócrata iquiqueña hacia el socialismo, bajo el impulso de Luis Emilio Recabarren ${ }^{16}$. Posteriormente, Julio Pinto publicó, conjuntamente con Verónica Valdivia, un libro referido a la competencia entre el socialismo y el alessandrismo por la politización pampina entre 1911 y 1932, en el que se trató la historia del POS en la región del salitre a partir de la lucha librada por Recabarren al interior del PD en 1911 y $1912^{17}$. Por su parte, Francisco Sepúlveda Gallardo dedicó su tesis de Licenciatura en Historia a la trayectoria del PD en Tarapacá entre 1899 y 1909, incluyendo una revisión del asentamiento definitivo de ese parti-

12 Sergio Grez Toso, Les mouvements d'ouvriers et d'artisans en milieu urbain au Chili au XIXème siècle (1818-1890), Thèse de Doctorat (nouveau régime) en Histoire et Civilisations, École des Hautes Études en Sciences Sociales, Paris, 1990.

13 Sergio Grez Toso, "Los primeros tiempos del Partido Democrático chileno (1887-1891)", Dimensión Histórica de Chile 8, Santiago, 1991, 31-62; "Balmaceda y el movimiento popular", Sergio Villalobos et al., La época de Balmaceda, Santiago, DIBAM, 1992, 71-101; De la "regeneración del pueblo" a la huelga general. Génesis y evolución histórica del movimiento popular en Chile (1810-1890), Santiago, DIBAM-RIL Ediciones, 1998, especialmente 655-703.

14 Julio Pinto Vallejos, "En el camino de la Mancomunal: organizaciones obreras en la provincia de Tarapacá, 1880-1895", Cuadernos de Historia 14, Santiago, diciembre de 1994, 81-135.

15 Julio Pinto Vallejos, “¿Cuestión social o cuestión política? La lenta politización de la sociedad popular tarapaqueña hacia el fin de siglo (1889-1900)", Julio Pinto Vallejos, Trabajos y rebeldias en la pampa salitrera. El ciclo del salitre y la reconfiguración de las identidades populares (1850-1900), Santiago, Editorial Universidad de Santiago, 1998, 251-312.

16 Julio Pinto Vallejos, "Socialismo y salitre: Recabarren, Tarapacá y la formación del Partido Obrero Socialista", Historia 32, Santiago, 1999, 315-366.

17 Julio Pinto y Verónica Valdivia, ¿Revolución proletaria o querida chusma? Socialismo y Alessandrismo en la pugna por la politización pampina (1911-1932), Santiago, Lom Ediciones, 2001, 23-31. 
do en Tarapacá a partir de 1899, las inflexiones que los demócratas introdujeron a su línea general para adaptarla a las realidades provinciales, las diferencias y fraccionamientos surgidos en el seno de "la Democracia" tarapaqueña a partir de 1901 y el ascenso y legitimación social del PD en Tarapacá hacia el término de la primera década del siglo $\mathrm{XX}^{18}$. En una monografía sobre la Mancomunal iquiqueña, Pablo Artaza se explayó sobre las contradicciones entre esa organización sociopolítica y el PD, y en otros textos incursionó sobre la evolución del PD tarapaqueño con posterioridad a la masacre de la Escuela Santa María, caracterizando esos años como un período de "ascenso y radicalización" del partido, que culminarían en 1912 con su transformación -o al menos la de una fracción muy importante- en el POS ${ }^{19}$. Algunos aspectos de la política del PD en Tarapacá, con énfasis en el papel desempeñado por Osvaldo López, dirigente de la agrupación iquiqueña, fueron relevados por Sergio González Miranda en un libro sobre el movimiento de emancipación de los trabajadores pampinos en torno a 1907, año de la matanza de la Escuela Santa María de Iquique ${ }^{20}$.

Otro aporte al conocimiento de una experiencia local de la política demócrata en los últimos años del siglo XIX y comienzos del siglo XX fue realizado por Jorge Muñoz Sougarret, en su tesis de Magíster en Historia sobre la implantación del régimen salarial en el Departamento de Osorno. Este autor trató brevemente las divisiones que sufrió la agrupación osornina del PD a partir de 1905 y su incapacidad de "leer" bien la realidad de la zona, lo que redundó en su escasa influencia hasta, por lo menos, la primera década del nuevo siglo ${ }^{21}$.

María Angélica Illanes, en tres trabajos referidos a otras temáticas, entregó antecedentes para la comprensión de la política municipal de este partido entre 1888 y $1891^{22}$; su oposición al servicio militar obligatorio ${ }^{23}$; y, muy brevemente, algunos elementos de su política en el período inmediatamente posterior a la guerra civil de $1891^{24}$. Pablo Toro Blanco investigó el papel del PD en la gestación de la Ley de Instrucción Primaria Obligatoria y realizó un interesante estudio prosopográfico de los

18 Francisco Sepúlveda Gallardo, Trayectoria y proyección histórica del Partido Demócrata en Tarapacá. 1899-1909, Tesis para optar al grado de Licenciado en Educación en Historia y Geografía, Universidad de Santiago de Chile, 2003.

19 Pablo Artaza Barrios, "La Sociedad Combinación Mancomunal de Obreros de Iquique y la huelga de diciembre de 1907”, Pablo Artaza et al., A 90 años de los sucesos de la Escuela Santa María de Iquique, Santiago, DIBAM-Universidad Arturo Prat, 1998, 11-31; "El impacto de la matanza de la Escuela Santa María de Iquique. Conciencia de clase, política popular y movimiento social en Tarapacá", Cuadernos de Historia 18, Santiago, diciembre de 1998, 169-227; Movimiento social y politización popular en Tarapacá 1900-1912, Concepción, Ediciones Escaparate, 2006.

20 Sergio González Miranda, Ofrenda a una masacre. Claves e indicios históricos de la emancipación pampina de 1907, Santiago, Lom Ediciones, 2007, 137-149.

${ }^{21}$ Jorge Muñoz Sougarret, Implementación del régimen salarial en el Departamento de Osorno, 1880-1907. De migrante campesino a obrero de la Mancomunal, Tesis para optar al grado de Magíster en Ciencias Humanas con mención en Historia, Universidad de Los Lagos, Osorno, 2009.

${ }^{22}$ María Angélica Illanes, "El proyecto comunal en Chile" (Fragmentos) 1810-1891”, Historia 27, Santiago, 1993, 213-229.

23 María Angélica Illanes, "Lápiz versus fusil. Las claves del advenimiento del nuevo siglo. SantiagoIquique, 1900-1907”, Artaza et al., A 90 años..., op. cit., 192-208.

24 María Angélica Illanes, Cuerpo y sangre de la política. La construcción histórica de las Visitadoras Sociales (1887-1940), Santiago, Lom Ediciones, 2007, 57-65. 
parlamentarios demócratas hasta 1920, apoyándose fundamentalmente en los datos de las Biografías de Chilenos, que entonces preparaba Armando de Ramón ${ }^{25}$. En un artículo sobre educación, Loreto Egaña evocó de paso la participación de algunos parlamentarios demócratas en la discusión y aprobación de esa ley ${ }^{26}$. Jorge Rivas y Eduardo Cortés reconstruyeron importantes pasajes de la historia de la Agrupación Demócrata de la capital entre 1905 y 1909, en particular su vínculo con algunos movimientos de la clase obrera santiaguina y la participación en coyunturas electora$\operatorname{les}^{27}$. Sergio González, María Angélica Illanes y Luis Moulian realizaron una importante contribución documental en una antología de la poesía popular aparecida en la prensa demócrata iquiqueña entre 1899 y 1910. El estudio introductorio de Moulian reconstituyó con cierto detalle la historia de los periódicos demócratas El Pueblo y El Pueblo Obrero ${ }^{28}$. Patricio de Diego Maestri, Luis Peña Rojas y Claudio Peralta Castillo se refirieron tangencialmente a la relación del PD con la Asamblea Obrera de Alimentación Nacional (AOAN), destacando algunas posiciones asumidas por sus parlamentarios y ministros ${ }^{29}$. Algo similar -aunque con algo más de atención en los demócratas- hizo Ignacio Rodríguez Terrazas en su tesis de Licenciatura de Historia sobre el mismo tema ${ }^{30}$.

Por nuestra parte, en un par de artículos referidos a temas más amplios, hemos profundizado aspectos del papel desempeñado por el PD en la "huelga de los tranvías" (abril de 1888) y en la "huelga de la carne" (octubre de 1905) ) $^{31}$ Igualmente, hemos examinado tangencialmente la posición demócrata respecto de las huelgas y métodos de lucha de la clase obrera, entre la guerra civil de 1891 y la masacre de la Escuela Santa María de Iquique en $1907^{32}$. También hemos explorado la posición demócrata sobre la emergente legislación social y los mecanismos de conciliación y arbitraje entre 1903 y $1924^{33}$.

25 Pablo Toro Blanco, "Una mirada a las sociabilidades educacionales y a las doctrinas de la élite y de los artesanos capitalinos frente a la demanda social por instrucción primaria, 1856-1920", Tesis para optar al grado de Licenciado en Historia, Pontificia Universidad Católica de Chile, Santiago, 1995.

${ }^{26}$ María Loreto Egaña, "La ley de Instrucción Primaria Obligatoria: un debate político", Mapocho 41, Santiago, primer semestre de 1997, 169-191.

27 Eduardo Cortés A. y Jorge Rivas M., De forjadores a prescindibles: el movimiento obrero popular urbano y el Partido Democrático. Santiago 1905-1909, Tesis para optar al grado de Licenciado en Historia, Universidad de Santiago de Chile, 1999.

28 Sergio González, María Angélica Illanes y Luis Moulian, Poemario popular de Tarapacá 18991910, Santiago, DIBAM-Lom Ediciones-Universidad Arturo Prat, 1998.

29 Patricio de Diego, Luis Peña Rojas y Claudio Peralta Castillo, La Asamblea Obrera de Alimentación Nacional. Un hito en la historia de Chile, Santiago, Sociedad Chilena de Sociología Universidad Academia de Humanismo Cristiano, 2002.

${ }^{30}$ Ignacio Rodríguez Terrazas, Protesta y soberanía popular: las marchas del hambre en Santiago de Chile 1918-1919, Tesis para optar al grado de Licenciado en Historia, Pontificia Universidad Católica de Chile, Santiago, 2000.

31 Sergio Grez Toso, "Una mirada al movimiento popular desde dos asonadas callejeras (Santiago, 1888-1905)", Cuadernos de Historia 19, Santiago, diciembre de 1999, 157-193.

32 Sergio Grez Toso, "Transición en las formas de lucha. Motines peonales y huelgas obreras (Chile, 1891-1907)", Historia 33, Santiago, 2000, 141-225.

33 Sergio Grez Toso, "El escarpado camino hacia la legislación social: debates, contradicciones y encrucijadas en el movimiento obrero y popular (Chile: 1901-1924)", Cuadernos de Historia 37, Santiago, 
Juan Carlos Yáñez analizó el papel de los demócratas en la discusión y aprobación de las leyes sociales durante las primeras décadas del siglo XX, y también estudió las influencias ideológicas y políticas -entre ellas la del PD- que pesaron sobre los movimientos de los obreros panificadores chilenos, entre 1888 y $1930^{34}$.

Además de lo ya señalado, debemos consignar que varios investigadores han continuado aportando al conocimiento de aspectos parciales de la política demócrata. En su libro consagrado al género, políticas y trabajo en Chile urbano entre 1900-1930, Elizabeth Q. Hutchison abordó el papel y el aporte de los militantes del PD (hombres y mujeres), especialmente de su ala izquierda, en la formación del feminismo obrero y en el impulso de periódicos e instituciones preocupados más específicamente de la condición y reivindicaciones femeninas en el seno del movimiento obrero ${ }^{35}$. Desde una perspectiva muy similar a la anterior, pero con énfasis en las contradicciones en la vida familiar de los hombres y mujeres del movimiento obrero, Claudia Jeria Valenzuela se refirió a las posiciones demócratas sobre clase y género y destacó el papel desempeñado por un puñado de mujeres que militaron en el PD a comienzos del siglo $\mathrm{XX}^{36}$. Michael Reynolds trató la influencia de este partido en la mutación de sociedad de resistencia a sociedad mancomunal de la Federación de Trabajadores del carbón de Lota y Coronel, en los primeros años del siglo $\mathrm{XX}^{37}$.

Los debates de los demócratas con otras corrientes que se disputaban la conducción del movimiento obrero y popular han sido bastante estudiados. En nuestros libros sobre el anarquismo y el comunismo chileno de fines del siglo XIX y las primeras décadas del siglo XX, pasamos revista de manera detallada a las polémicas entre el PD, los anarquistas, los primeros socialistas y los comunistas, dando cuenta de los trasvasijes de militantes entre esas corrientes ${ }^{38}$. También constituye una valiosa contribución para entender la lucha ideológica interna al interior del PD hasta la escisión de su ala izquierda que dio origen al POS, el libro de Jaime Massardo referido a la formación del imaginario político de Luis Emilio Recabarren, que, como es sabido, militó en el PD hasta mediados de $1912^{39}$. La obra de Massardo, de gran fineza teó-

diciembre de 2001, 119-182; “¿Autonomía o escudo protector? El movimiento obrero y popular y los mecanismos de conciliación y arbitraje (Chile, 1900-1924)”, Historia 35, Santiago, 2002, 91-150.

34 Juan Carlos Yáñez, Estado, consenso y crisis social. El espacio público en Chile: 1900-1920, Santiago, Centro de Investigaciones Diego Barros Arana, 2003; La intervención social en Chile 19071932, Santiago, RIL Editores, 2008, 144 y siguientes; "Por una legislación social en Chile. El movimiento de los panaderos (1888-1930)", Historia 41:2, Santiago, diciembre de 2008, 495-532.

35 Elizabeth Q. Hutchison, Labores propias de su sexo. Género, politicas y trabajo en Chile urbano 1900-1930, Santiago, Lom Ediciones - Centro de Investigaciones Diego Barros Arana, 2006.

${ }^{36}$ Claudia Jeria Valenzuela, Hombres y mujeres en conflicto. Clase y género en la familia proletaria, Santiago, 1900-1910, Tesis para optar al grado de Licenciada en Historia y Ciencias Sociales, Universidad de Santiago de Chile, 2007.

37 Michael Reynolds, Movimiento mancomunal y conciencia de clase en la frontera carbonífera 1903-1907, Seminario para optar al grado de Licenciado en Historia y Ciencias Sociales, Universidad ARCIS, Santiago, 2006.

38 Sergio Grez Toso, Los anarquistas y el movimiento obrero. La alborada de "la Idea" en Chile, 1893-1915, Santiago, Lom Ediciones, 2007, 159-177; Historia del comunismo en Chile, La era de Recabarren (1912-1924), Santiago, Lom Ediciones, 2011, especialmente 23-33.

39 Jaime Massardo, La formación del imaginario político de Luis Emilio Recabarren. Contribución 
rica, se apoya en un impresionante acopio de fuentes nacionales e internacionales, sumándose de esta manera a trabajos muy antiguos sobre Recabarren. Entre estos últimos conviene destacar los de Fernando Alegría, César Godoy Urrutia, Julio César Jobet, Alejandro Witker e Iván Lubjetic ${ }^{40}$, y otros más recientes referidos a la contribución de este líder obrero al pensamiento, la cultura y el proyecto popular, como, por ejemplo, los de Augusto Samaniego, Gabriel Salazar, Manuel Loyola y Miguel Silva $^{41}$. Todo lo anterior sin considerar las compilaciones de los escritos de Recabarren realizadas por Julio César Jobet, Luis Vitale y Jorge Barría ${ }^{42}$, y Eduardo Devés y Ximena Cruzat ${ }^{43}$. Mencionamos estas obras referidas a Recabarren y las compilaciones de sus escritos porque, de alguna manera, a través del estudio de la evolución ideológica de este líder -especialmente hasta 1912-, es posible conocer aspectos muy importantes de las luchas internas en el seno del PD.

Además de las obras indicadas, existen numerosas obras generales que contienen menciones e interpretaciones de diversa profundidad sobre la historia del PD, destacando, entre otras, el libro de Julio Heise González referido al período parlamentario, el que -a pesar de su visión esencialmente conservadora de la historia- entrega interesantes datos acerca del peso electoral y parlamentario de los partidos políticos, incluyendo al $\mathrm{PD}^{44}$; la maciza Historia política de Chile y su evolución electoral de Germán Urzúa Valenzuela, que da cuenta, elección tras elección, de los caudales de votos obtenidos por todas las fuerzas políticas ${ }^{45}$; y la Historia de Chile de Gonzalo Vial Correa, en particular los volúmenes I, tomo II y III, que abarcan el período y las temáticas que nos interesan. Esta obra, a semejanza de la de Heise, a pesar de su

al estudio crítico de la cultura política de las clases subalternas de la sociedad chilena, Santiago, Lom Ediciones, 2008, 151-178.

40 Fernando Alegría, Recabarren, Santiago, Editorial Antares, 1938; César Godoy Urrutia, "Vida y obra de Recabarren", Principios 141-142, Santiago, septiembre-diciembre de 1941; Julio César Jobet, Recabarren y los orígenes del movimiento obrero y del socialismo chileno, Santiago, PLA, 1955; “Trayectoria ejemplar de Luis Emilio Recaberren", Arauco 59, Santiago, diciembre de 1964, 71-77; "El pensamiento político de Recabarren", Recabarren. Obras Selectas, Santiago, Quimantú, 1971; Alejandro Witker, Los trabajos y los días de Recabarren, La Habana, Editorial Nuestro Tiempo, 1977; Iván Ljubetic V., Don Reca, Santiago, Instituto de Ciencias Alejandro Lipschutz, 1992.

${ }^{41}$ Augusto Samaniego, “Quiénes crearán el instrumento socialista? Recabarren, demócratas y socialistas (1907-1908). Dos textos", Contribuciones Cientificas y Tecnológicas 127, Santiago, mayo de 2001, 1-21; Gabriel Salazar V., Movimiento social, municipio y construcción de Estado: el liderazgo de Recabarren (1910-1925), Santiago, Documento de trabajo No131, SUR, octubre de 1992; "Luis Emilio Recabarren y el municipio en Chile (1900-1925)", Revista de Sociología 9, Santiago, 1994; Manuel Loyola, La felicidad y la política en Luis Emilio Recabarren. Ensayo de interpretación de su pensamiento, Santiago, Ariadna Ediciones, 2007; Miguel Silva, Recabarren y el socialismo, Santiago, Taller Artes Gráficas Apus, 1992.

42 Julio César Jobet, Jorge Barría y Luis Vitale, Obras Selectas de Luis Emilio Recabarren, Santiago, Empresa Editora Quimantú, 1971.

43 Ximena Cruzat y Eduardo Devés, Recabarren. Escritos de prensa, 4 volúmenes, Santiago, Editorial Nuestra América y Terranova Limitada, 1985-1987.

44 Julio Heise González, El período parlamentario. 1861-1925. Tomo II: Democracia y gobierno representativo en el período parlamentario (historia del poder electoral), Santiago, Editorial Universitaria, 1982.

${ }^{45}$ Germán Urzúa Valenzuela, Historia politica de Chile y su evolución electoral (desde 1810 a 1992), Santiago, Editorial Jurídica de Chile, 1992. 
sesgo conservador, contiene riquísimas informaciones y valiosos alcances sobre un sinnúmero de cuestiones políticas, culturales y sociales ${ }^{46}$. En un par de trabajos de J. Samuel Valenzuela sobre los orígenes y transformaciones del sistema político chileno se dedican varias páginas al $\mathrm{PD}$, con observaciones bastante perspicaces, a pesar de que en el momento de ser publicados (1985 y 1995, respectivamente) se carecía de sólidas monografías sobre este partido en las que basarse con gran seguridad. Ello explica, probablemente, que en su libro sobre la expansión del sufragio en Chile sostuviera que el PD tuvo "una participación electoral y política bastante exitosa hasta la década de los veinte" transformaciones en el sistema de partidos en Chile publicado diez años más tarde, hablara de un "relativo fracaso electoral" de este partido ${ }^{48}$. Con todo, sus reflexiones acerca de la política electoral demócrata y sus explicaciones acerca de los resultados obtenidos por este partido son particularmente interesantes, debiendo ser cotejadas con los resultados de investigaciones más profundas.

Abreviando el balance, podemos decir que si bien en las últimas décadas el creciente interés de los historiadores por el PD ha permitido reconstruir fragmentos importantes de su historia, no es menos cierto que subsisten numerosos aspectos y pasajes sobre los que se ha acumulado muy poco conocimiento. El presente artículo pretende llenar uno de esos vacíos historiográficos, reconstituyendo y analizando de manera pormenorizada el itinerario que llevó al PD, en los últimos años del siglo XIX, a ingresar a Alianza Liberal e incorporarse de lleno al parlamentarismo de aquella época, cuestión que si bien ha sido mencionada innumerables veces, hasta ahora no ha sido objeto de un estudio específico. Para explicar este fenómeno formulamos como hipótesis que el PD tuvo dos motivaciones básicas que se entrelazaron estrechamente y que hicieron indefectible su convergencia con la Alianza Liberal y participación en el juego parlamentarista. Un motivo ideológico: su anticonservadurismo y anticlericalismo; y un motivo práctico: la necesidad de "defender" las diputaciones obtenidas en el momento de la calificación de las elecciones por los parlamentarios, lo que lo obligaba a buscar aliados. Ambos motivos se desprendían, a la vez, del carácter reformista de este partido, de su autoidentificación con el liberalismo - como su ala plebeya, más decidida y consecuente- y de su proyecto de reforma democrática del Estado oligárquico.

\section{LOS DESGARRAMIENTOS DE LA GUERRA CIVIL DE 1891}

La guerra civil de 1891 desarticuló por completo al PD. El conflicto entre partidarios y opositores al gobierno de Balmaceda -opción a la que el partido se había resis-

${ }^{46}$ Gonzalo Vial Correa, Historia de Chile (1891-1973), Santiago, Zig-Zag, 1988-2001, vol. I, tomo II y vol. III

47 Valenzuela, Democratización..., op. cit., 45.

48 J. Samuel Valenzuela, "Origen y transformaciones del sistema de partidos en Chile", Estudios Públicos 58, Santiago, otoño de 1995, 28-36. La afirmación citada en página 32. 
tido hasta fines de 1890- provocó enconados rencores en su seno. Aun cuando resulta casi imposible evaluar exactamente los porcentajes de adherentes que los bandos demócratas en pugna lograron alinear tras de sí, lo cierto es que la inmensa mayoría de los dirigentes y probablemente también de los militantes de base terminaron, de buen grado o a regañadientes, escogiendo un campo. Muy pocas figuras destacadas del PD -como Donato Millán- guardaron prudente neutralidad ${ }^{49}$. Las agrupaciones demócratas se inclinaron masivamente a favor de uno u otro bando o se dividieron sin llegar a un acuerdo común. Las agrupaciones de Valparaíso, Chillán, Quillota e Iquique, entre otras, se matricularon decididamente a favor de "la revolución" y contra "el dictador" Balmaceda, mientras que en Santiago, lugar de residencia de la mayoría de los líderes nacionales, el grueso de ellos se pronunció por el apoyo al gobierno. Seguramente ocurrió algo similar en su base ${ }^{50}$.

Las divisiones, recriminaciones, anatemas y expulsiones mutuas dejaron al partido hecho añicos, manteniéndose las odiosidades internas durante algún tiempo después de finalizada la guerra civil. Con todo, el nuevo cuadro político que surgió en el último trimestre de 1891 hizo que muy rápidamente empezaran a surgir algunos puntos de convergencia entre los demócratas divididos por la contienda fratricida.

En la fracción demócrata que había apoyado a los alzados congresistas comenzó la desazón por los resultados de "la revolución". ¿Quiénes habían triunfado realmente? ¿Representaban los vencedores los intereses populares, o, al menos, estaban dispuestos a hacerles un espacio en sus programas y actos de gobierno? ¿Aplicarían una política de clemencia con los vencidos y de reconciliación nacional o, por el contrario, incurrirían en el revanchismo, el sectarismo y la siembra de más odios?

Los demócratas que se habían levantado junto a los "revolucionarios" contra "el tirano" Balmaceda, mantuvieron durante un breve lapso sus ilusiones en los nuevos gobernantes ${ }^{51}$. Pero desde los primeros meses del nuevo poder, aquellos demócratas que habían luchado por su entronización sintieron que sus esperanzas se frustraban. Los oligarcas que habían derrocado a Balmaceda no los consideraban y, peor aún, sus políticas tenían el sello aristocrático de siempre. Al comienzo fueron solo indicios o actos más bien simbólicos, sin embargo, muy rápidamente la sensación de haber sido utilizados se apoderó de estos militantes, que comenzaron a tomar distancia crítica respecto de su propia actuación en la guerra civil y propugnaron una política más independiente frente al poder.

En realidad, los demócratas solo habían cosechado sinsabores de su participación en la guerra civil. Apenas estalló el conflicto armado, algunos militantes y dirigentes de la agrupación iquiqueña, como César Augusto Cáceres, conductor de la huelga

49 Un relato histórico pormenorizado y un análisis de las contradicciones entre el PD y el gobierno de Balmaceda, y acerca de las repercusiones en el seno del propio PD, se encuentra en Grez, De la “regeneración..., op. cit., 702 y 703.

${ }^{50}$ Idem.

51 Véanse, a modo de ejemplo de estas esperanzas, los siguientes artículos publicados en la prensa demócrata: Fas, "Interior. A. S.E. don Jorge Montt (Colaboración)", El Pueblo, Valparaíso, 5 y 12 de diciembre de 1891; Fas, "Colaboraciones. A S. E. don Jorge Montt”, El Pueblo, Valparaíso, 2 de enero de 1892. 
general de 1890, y el director José Antonio Miranda fueron encarcelados por las autoridades balmacedistas ${ }^{52}$. Más tarde, aquellos líderes nacionales que, como Malaquías Concha, Juan Rafael Allende, Avelino Contardo y Victorino Stella, prefirieron apoyar al gobierno de Balmaceda, corrieron la suerte de los vencidos sufriendo vejámenes y cárcel $^{53}$. Antonio Poupin, presidente del partido, que optó por el bando que a la postre resultaría victorioso, pagó con su vida la participación en la lucha armada del lado de los insurrectos. El mismo fin tuvo el dirigente penquista Ernesto Rossel, quien pereció combatiendo con el grado de capitán en las filas congresistas en la batalla de Placilla ${ }^{54}$. Otros militantes fueron humillados después de haber servido a los vencedores, como le ocurrió a Juan Segundo Leiva, secretario de la agrupación demócrata de Iquique, quien durante la guerra civil fue enviado por sus correligionarios del puerto tarapaqueño a los buques de la Armada para acompañar al movimiento subversivo contra el gobierno central y "una vez a bordo fue tratado con soberano desdén por los jefes de la oposición y hasta se le consideró como un espía de Balmaceda" ${ }^{55}$.

\section{EL DIFÍCIL CAMINO HACIA LA UNIDAD INTERNA}

A partir de la toma de conciencia autocrítica de su desafortunado papel durante la guerra civil, el acercamiento entre ambas fracciones del partido era posible. La agrupación de Chillán propuso la realización de una convención en su ciudad, el 12 febrero de 1892, a fin de concretar la anhelada reunificación. Los gestos apaciguadores de la controversia se multiplicaron. El 20 de noviembre de 1891 (cuarto aniversario de la fundación del partido), la agrupación de Parral dirigió una circular a sus congéneres de toda la república para solicitar moderación a la fracción demócrata santiaguina, aliada a los vencedores de la guerra civil, que había decretado la expulsión de connotados dirigentes de la fracción contraria acusados de "traición a su patria", entre los que se contaban Malaquías Concha, Artemio Gutiérrez, José Miguel Saldaña, Moisés González, Ismael Arriaza y Juan Rafael Allende. Los demócratas parralinos propusieron suspender "todo juicio de expiación" y saldar las diferencias en una convención nacional, para "unificar ideas" y "condenar a los tránsfugas que con antecedentes suficientes merezcan ser expulsados del seno de la democracia" ${ }^{56}$. La idea fue

52 Pinto Vallejos, “¿Cuestión social o cuestión política?”, op. cit., 271.

53 Archivo Histórico Nacional (en adelante AHN), Fondo Judicial Santiago, Causas Criminales, Proceso Político contra Dn. Malaquías Concha; "Nuestro candidato Victorino Stella", El Siglo XX, Santiago, 16 de noviembre de 1901.

54 "Memoria anual que presenta el Presidente de la Agrupación Democrática de Concepción, leída en asamblea de 11 de agosto de 1892", El Demócrata, Concepción, 23 de agosto de 1892.

55 “Don José $2^{\circ}$ Leyba", El Pueblo, Valparaíso, 16 de enero de 1892. En algunas fuentes este dirigente aparece como Juan Segundo, en otras como José Segundo Leiva. En todo caso, se trata de la misma persona.

56 "Más circunspección señores demócratas" [Editorial], El Día, Parral, reproducido en El Pueblo, Valparaíso, 2 de enero de 1892. En la jerga demócrata, "la Democracia" (casi siempre con mayúscula) era el PD, tanto sus principios como su organización. 
acogida inmediatamente por las agrupaciones de Penco, Los Ángeles, Collipulli, San Carlos y San Felipe ${ }^{57}$.

Aunque la agrupación de Valparaíso no se sumó explícitamente a la iniciativa de su similar de Parral, en los hechos impulsó la misma solución. El 2 de febrero de 1892, la agrupación porteña aprobó una moción de tono conciliatorio, presentada por su presidente Manuel Serey, que, entre otros puntos, prohibía absolutamente a sus miembros "en el seno de la asamblea de hacer alusión alguna a la lucha pasada ya a favor ya en contra de alguno de los bandos que tomaron parte directiva en la contienda" 58 .

A pesar de los esfuerzos desplegados, ni la crisis se superó prontamente, ni el partido recobró su unidad durante la convención realizada en el verano 1892 en Chillán. La agrupación de Concepción contestó el procedimiento adoptado por su homóloga chillaneja por considerarlo antirreglamentario (puesto que el Reglamento de 1889 prescribía que seis agrupaciones debían solicitar al Directorio General la realización de una convención extraordinaria). Sin embargo, la agrupación de Chillán, encabezada por Ángel Custodio Oyarzún, mantuvo la convocatoria, argumentando que el Directorio General no existía, puesto que dos de sus miembros habían muerto y tres habían sido marginados por la agrupación de Santiago. Al evento concurrieron delegados de Limache, Talca, Parral, San Carlos, Bulnes, Talcahuano, Los Ángeles, Mulchén y de una fracción santiaguina, además de la agrupación anfitriona. Los representantes de Valparaíso y La Serena se retiraron sin tomar parte en las deliberaciones, porque sus instrucciones los autorizaban a hacerlo solo si estaban representadas todas las agrupaciones ${ }^{59}$.

A las profundas heridas del reciente enfrentamiento civil se sumaban nuevas contradicciones, que complotaban contra el propósito de recobrar la armonía y poderío pasado del PD. Luego de retirarse sin presentar sus poderes ante la Convención de Chillán, la agrupación de Valparaíso formuló duras críticas a través de su órgano de prensa. Según los demócratas porteños, dicha reunión, en vez de contribuir a la unión, había sembrado la desconfianza entre las agrupaciones demócratas, puesto que en ella no se había discutido sobre conveniencias y razones, sino acerca de personalidades; se había dado paso a la influencia de círculo, no se habían olvidado los agravios, se habían dado "alas a la malquerencia" y pisoteado el reglamento del partido en lo más esencial ${ }^{60}$. De manera más precisa, se reprochaba a la convención chillaneja haber elevado al cargo de director general del partido a Donato Millán, quien había sido expulsado de la agrupación de Santiago antes de la guerra civil, y haber reconocido a una de las dos fracciones que se disputaban la representación del partido en la capital ${ }^{61}$.

\footnotetext{
57 Idem.

58 “Asamblea democrática”, El Pueblo, Valparaíso, 6 de febrero de 1892.

59 "La Convención Democrática de Chillán y la Agrupación de Concepción”, El Demócrata, Concepción, 19 de marzo de 1892.

60 "La Convención de Chillán”, El Pueblo, Valparaíso, 20 de febrero de 1892.

${ }^{61}$ Idem.
} 
Por su parte, la agrupación penquista continuó negando toda validez al evento realizado en Chillán, calificándolo de ilegal, inoportuno y perjudicial, especialmente por su decisión de expulsar a algunos dirigentes del partido que habían apoyado a Balmaceda en la guerra civil ${ }^{62}$. En el mismo registro, el 10 de abril, una concurrida asamblea de la agrupación de Santiago (o de su sector mayoritario), acordó "desconocer en absoluto la validez de los acuerdos" de dicha convención y "condenar enérgicamente la conducta perturbadora y anárquica" del director general Ángel Custodio Oyarzún, principal impulsor de la reunión de Chillán ${ }^{63}$.

A pesar de la persistencia de viejos y nuevos rencores, la evolución de la situación política y el agravamiento de la condición económica de los sectores populares empujaban a los demócratas a realizar nuevos esfuerzos en aras de su unidad. El cogobierno de liberales y conservadores molestaba e inquietaba a los militantes del partido $^{64}$. El alza de los artículos de primera necesidad, especialmente de los arriendos y vestimentas, y la política económica del gobierno contribuyeron poderosamente a disipar las últimas ilusiones de algunos demócratas respecto de la "revolución" de $1891^{65}$.

Aguijoneados por esta realidad tan adversa, los demócratas realizaron nuevas tentativas de reunificación. La asamblea realizada en Santiago en abril de 1892 acordó "adoptar como norma invariable de conducta el más completo olvido de toda diferencia o desacuerdo que traiga origen en la pasada guerra civil", a fin de unir estrechamente a todos los militantes y convocar a todos los hombres de bien que aspiraran a la implantación del régimen de gobierno popular y representativo establecido por la Constitución ${ }^{66}$.

Desde distintos puntos del país se alzaron voces exigiendo una convención con estricto apego a las prescripciones del reglamento y en la que estuvieran representadas todas las agrupaciones partidarias ${ }^{67}$. Pero la convención que tuvo lugar en Santiago el 14 de julio de 1892 arrojó resultados muy modestos. Solo concurrieron delegaciones de ocho agrupaciones: Iquique, Valparaíso, Quillota, Santiago, Parral, Los Ángeles, Concepción y Talcahuano. Las agrupaciones de Mulchén, La Serena y Limache, aunque no enviaron delegados, prometieron acatar sus acuerdos; las de Bulnes, San Carlos y San Felipe no se hicieron presentes y no se pronunciaron; la agrupación talquina protestó, alegando que la convención debía realizarse en su ciudad; y la de Chillán, a través de Ángel Custodio Oyarzún, le restó toda legitimidad ${ }^{68}$. Ante este poco alentador panorama, la Convención de Santiago decidió, "como una prueba de confraternidad y compañerismo hacia las agrupaciones hermanas no repre-

62 "La Convención Democrática de Chillán y la agrupación de Concepción", El Demócrata, Concepción, 2 de abril de 1892. Véase también, "Convención Democrática", El Demócrata, Concepción, 9 de julio de 1892 .

63 "Gran asamblea en Santiago", El Demócrata, Concepción, 16 de abril de 1892.

64 “Actualidad”, El Pueblo, Valparaíso, 27 de febrero de 1892.

65 “¡Pobre Chile!”, El Pueblo, Valparaíso, 9 de abril de 1892.

66 "Gran asamblea en Santiago", op. cit.

67 Véase, a modo de ejemplo, "A la unión" [Editorial], El Demócrata, Concepción, reproducido en El Pueblo, Valparaíso, 9 de abril de 1892.

68 “Convención Democrática de Santiago”, El Demócrata, Concepción, 23 de julio de 1892. 
sentadas, suspender toda clase de trabajos hasta el 20 de noviembre" ${ }^{69}$. Un directorio encabezado por dirigentes de las dos fracciones demócratas que se habían enfrentado durante la guerra civil fue el único resultado tangible de esta reunión. Los delegados de Valparaíso, Manuel Serey y Ángel Guarello, fueron elegidos presidente y secretario, respectivamente, mientras que Malaquías Concha, representante de la agrupación santiaguina, fue nombrado secretario ${ }^{70}$. La completa reunificación demócrata quedó postergada hasta la convención que en noviembre debería realizarse en Parral.

Entretanto, una elección senatorial complementaria por Santiago, que debía tener lugar el 12 de septiembre, permitió que los demócratas de la capital probaran sus fuerzas. El candidato escogido por los militantes santiaguinos fue Donato Millán, quien, aparte de su indiscutible prestigio personal, tenía la ventaja de no haber tomado partido durante la guerra civil. De 3.000 sufragios emitidos (los balmacedistas se abstuvieron), Millán obtuvo 360 votos $^{71}$.

La Convención de Parral, realizada como estaba previsto el 20 de noviembre de 1892, puso fin -en teoría- a la división del partido. Según un estudio histórico realizado casi medio siglo después por De Petris Giesen, además de aprobarse un voto para pedir una ley de amnistía general para los presos políticos que habían apoyado a Balmaceda y acordar mantener la independencia y autonomía del partido, prohibiendo los pactos o alianzas con otras fuerzas, "en ella se cristalizó la más perfecta unidad de las Agrupaciones Demócratas separadas con motivo de la revolución del 91"72.

Contradiciendo este juicio optimista, numerosas evidencias permiten sostener que la dispersión orgánica, las divisiones y las rencillas continuaron reinando en la organización política popular. El Directorio General, radicado entonces en Valparaíso, tenía un ascendiente limitado sobre las distintas agrupaciones que existían a lo largo del país. Ángel Guarello, uno de los miembros más destacados de ese organismo, al ser interrogado en abril de 1893 por uno de los redactores del periódico demócrata penquista La Igualdad, sobre el estado de la prensa partidaria, reconoció que a la secretaría del partido llegaba regularmente solo El Centinela de Talca, sin que se tuvieran noticias de a lo menos siete u ocho órganos de prensa que los demócratas publicaban por esos días en La Serena, San Felipe, Parral, Chillán, Concepción, Santiago y en la propia ciudad de Valparaíso ${ }^{73}$. Por ello el Directorio General envió ese mismo mes una circular a sus militantes, prohibiéndoles que las publicaciones partidarias se declararan "órgano del Partido Democrático" sin expreso permiso escrito de esa directiva nacional, autorizando solamente a las agrupaciones para que presentaran sus periódicos como "órgano de la Agrupación" local e informando de ello al Directorio General ${ }^{74}$.

Lo peor, sin embargo, era la débil unidad política interna. A los recuerdos, cicatrices y agravios de la guerra civil se sumaban nuevos factores: querellas y ambiciones personales y de grupos, no siempre claramente explicitadas o respaldadas con ar-

\footnotetext{
69 Idem.

70 Idem.

71 De Petris Giesen, op. cit., 15.

72 Idem.

73 Luis Peña i Lara, "Es increíble", La Igualdad, Concepción, 22 de abril de 1893.

74 “Crónica. Notas”, La Igualdad, Concepción, 25 de agosto de 1893.
} 
gumentos políticos precisos, pero también tensiones y nuevas divisiones motivadas muchas veces por la tentación de establecer alianzas con partidos o fracciones partidarias del gran arco liberal.

\section{¿AUtonomía o UNiÓN CON LA “FAMILIA Liberal”?}

El PD había irrumpido abruptamente hacia fines de la década de 1880 en el escenario político extrainstitucional, logrando concitar, gracias al empuje de sus jóvenes militantes y su preocupación central por la "cuestión social", la simpatía de importantes segmentos del mundo popular. Durante sus primeros años de vida este partido se desarrolló como una fuerza "extraparlamentaria", centrando su trabajo en las organizaciones sociales populares (especialmente mutualistas), en la edición de periódicos, la agitación, la propaganda y el impulso a movilizaciones masivas para representar ante las autoridades las más sentidas demandas de los sectores populares. Esta línea de trabajo respondía, sin duda, a los ejes principales de su programa, que apuntaban a "la emancipación social, política y económica" del pueblo de Chile, pero también era el resultado de los enormes obstáculos que levantaba el elitista sistema político chileno de la época a una fuerza joven, ajena a la oligarquía y con pretensiones de convertirse en el paladín de los intereses populares. El "extraparlamentarismo" demócrata de esos primeros años había sido solo una imposición de las circunstancias, no una opción voluntaria. Sus dirigentes pensaban que con el correr del tiempo el desarrollo de la influencia del partido en el seno del pueblo le daría la fuerza suficiente para alcanzar una adecuada representación en los cuerpos electivos del Estado (Parlamento, municipalidades y otros), permitiendo de esta manera las reformas sociales y el advenimiento efectivo de un sistema político plenamente democrático ${ }^{75}$.

El régimen parlamentario que se instauró en Chile luego del término de la guerra civil de 1891 brindó al PD la posibilidad de conquistar mayor influencia social y un espacio en las instituciones estatales para, desde allí, empezar a hacer realidad sus proyectos de reforma social. Pero ello implicaba el pleno ingreso a un juego político que distaba mucho de la pureza original de la colectividad demócrata, puesto que implicaba pactos, alianzas y compromisos con otras fuerzas políticas (oligárquicas y burguesas) que necesariamente condicionarían la línea de acción del partido, provocando desazón y descontento entre muchos militantes y seguidores.

Durante los primeros años que siguieron al término de la guerra civil, la relación con los balmacedistas, reorganizados en el Partido Liberal Democrático, generó dinámicas contrapuestas, que pusieron en tensión al $\mathrm{PD}^{76}$. Acercamientos, rechazos,

75 Un amplio desarrollo de estos temas y otros relacionados con los primeros años de vida del Partido Democrático en Grez, De la “regeneración del pueblo"..., op. cit., 702 y 703.

${ }^{76}$ Sobre la recomposición y reorganización del balmacedismo después de su derrota en la guerra civil, véanse: Alejandro San Francisco, "La Gran Convención del Partido Liberal Democrático en 1893. Un hito en la reorganización del balmacedismo después de la guerra civil chilena de 1891", Historia, 36, Santiago, 2003, 333-377; "La incorporación del Partido Liberal Democrático (Balmacedista) al sistema 
seducción y rivalidad eran algunas de las reacciones y emociones que suscitaba entre los demócratas la novísima tienda política agrupada tras el recuerdo del "Presidente mártir". Otras alternativas -apoyar al gobierno de Jorge Montt o mantener la independencia del partido, aliarse o no con otros sectores del liberalismo para hacer frente a los conservadores- también se debatían con pasión en su seno. Los balmacedistas intentaron atraer a los demócratas y sus simpatizantes mediante un lenguaje y símbolos que se asemejaban a los suyos. De seguro La Democracia, nombre escogido por el primer periódico balmacedista publicado en Santiago después de la guerra civil, respondía, al menos en parte, a esa preocupación, tal como se reflejaba claramente en algunos de sus llamamientos a los demócratas:

"Los miles de chilenos caídos con Balmaceda han formado un partido nuevo que aún no ha recibido denominación oficial. Hoy, este partido se encuentra robusto y con un directorio de entusiastas e inteligentes ciudadanos. Creemos es llegado el caso de fijar un programa y dar una denominación [...] Existe el Partido Democrático, con programa y con bandera de colores definidos y claro. ¿No sería oportuno el discutir la conveniencia de formar parte integrante de este partido, aumentar sus filas y procurar la unión y fuerza con otros hombres que no son de nuestras ideas, que han sufrido la misma caída y que batallan como nosotros para que se implante en Chile el gobierno del pueblo por el pueblo, que es el gobierno democrático? ¿Qué línea nos separa? ¿El nombre? [...] Pero, por hoy no dejamos más que enunciada esta grave cuestión, que entraña el porvenir de un partido. ¿Cuál será este? Lo declaramos francamente después de oír la opinión de muchos correligionarios, el partido del porvenir será el que resulte de la unión en un solo cuerpo, en una sola agrupación de los liberales y demócratas, caídos de golpe rudo de la aristocracia dominante" 77 .

Los cantos de sirena del balmacedismo tuvieron cierto eco en algunos sectores del PD, hacia 1892 y 1893. Las persecuciones sufridas por los partidarios del difunto mandatario, su rápida reorganización y sus declaraciones de fe democrática engendraron ilusiones de convergencia entre militantes demócratas que parecían crecer en relación inversamente proporcional a la decepción que les provocaba la "revolución constitucional". Aunque al cabo de poco tiempo muchos demócratas empezaron a ver con suspicacia el surgimiento del nuevo partido balmacedista, las persecuciones y sufrimientos provocados por la represión posterior a la guerra civil operaban como una fuerza que empujaba al acercamiento entre demócratas y balmacedistas. En más de una ocasión, al estallar o descubrirse actividades sediciosas de los liberales democráticos, se involucró - sin duda injustamente- a los demócratas, como ocurrió al reprimirse un complot abortado la noche del 11 de diciembre de 1892 en Santiago, ocasión en la que, junto a una mayoría de balmacedistas, fueron a dar a la cárcel líderes demócratas como Concha, Arriaza, Ugalde y otros. En 1893 y 1894, con motivo de

parlamentario chileno, 1891-1894. Hacia una explicación pluricausal”, Boletín de la Academia Chilena de la Historia 112, Santiago, 2003, 279-323.

77 "El partido del porvenir o liberales i demócratas", La Democracia, Santiago, 10 de septiembre de 1892. 
situaciones similares, Malaquías Concha y otros correligionarios fueron nuevamente apresados o perseguidos ${ }^{78}$.

Los vencedores de la guerra civil también buscaban sumar al PD, especialmente en aquellas localidades en que una parte sustantiva de los dirigentes de esa colectividad habían apoyado la "revolución constitucionalista". Poco después del término de la contienda armada, los representantes de la coalición triunfadora propusieron un pacto electoral a la Agrupación Demócrata de Concepción (cuyo directorio había sostenido el levantamiento congresista), pero la menguada oferta hecha por los liberales, radicales y conservadores -solo dos puestos en el municipio y un elector a Presidente de la República- llevó a los demócratas penquistas a presentar seis candidatos a concejales municipales, dos electores de Presidente y uno para diputado. Todos lograron la victoria, salvo el candidato a diputado, lo que sirvió de estímulo para que la agrupación emprendiera un camino de autonomía electoral ${ }^{79}$.

La cuestión de fondo que estaba planteada en todas estas ocasiones era la política de alianzas. Los demócratas se encontraban complicados ante la disyuntiva de mantener su independencia o hacer causa común con los demás componentes de la "familia liberal", para derrotar al conservadurismo. En julio de 1893, el periódico demócrata penquista La Igualdad aseguraba que, conforme a lo acordado en la última convención partidaria (realizada en Parral), no debían pactarse alianzas con otros partidos, que el PD no necesitaba buscar alianzas para hacer triunfar su programa, ni mentores que lo alentaran y dirigieran ${ }^{80}$. Concordando con tal orientación, ese mismo mes Moisés González y Francisco Vargas Lazo, presidente y secretario del Directorio General, respectivamente, publicaron un breve comunicado dirigido a la agrupación de Santiago, a propósito de rumores e informaciones de prensa referidas a una supuesta alianza entre el PD y el Partido Radical, precisando que nada había acontecido que pudiera autorizar dichos rumores y que un artículo del reglamento partidario prohibía "terminantemente las alianzas con otros partidos", disposición que el directorio cumpliría fielmente ${ }^{81}$.

Pero a las pocas semanas, en agosto, motivado por la sensación de "peligro conservador" que compartía con muchos de sus compañeros, Cayetano Sepúlveda, miembro del directorio general del partido, envió una nota a sus correligionarios de ese cuerpo colegiado, para pedir la realización de una sesión de trabajo que determinara la conveniencia de convocar a una convención partidaria que resolviera si había que resignarse a la dominación conservadora o aceptar la unión con las demás organizaciones liberales en la próxima campaña electoral, puesto que, según su análisis,

\footnotetext{
78 "La conspiración”, La Democracia, Santiago, 28 de enero de 1893; "Crónica. Prisión de don Malaquías Concha", La Igualdad, Concepción, 13 de mayo de 1893; Pedro A. Gálvez V., "Malaquías Concha", Democracia, Santiago, 27 de abril de 1902. Sobre las tentativas putchistas del balmacedismo entre 1891 y 1894 , véase Vial, op. cit., II:108-114.

79 "Memoria anual que presenta el Presidente de la Agrupación Democrática de Concepción...”, op. cit.

80 "Alerta", La Igualdad, Concepción, 15 de julio de 1893.

${ }^{81}$ Moisés González y F. Vargas Laso, "A nuestros correligionarios de la Agrupación Democrática de Santiago", El Ferrocarril, Santiago, 30 de julio de 1893. Este documento también fue reproducido, entre otros, por La Igualdad, Concepción, 9 de agosto de 1893.
} 
debido al fraccionamiento y a la anarquía reinante en el liberalismo, era posible que dentro de poco tiempo el Partido Conservador se levantara como fuerza dominante, si el PD no trabajaba con gran tesón por salvar la República y sus instituciones ${ }^{82}$.

Para numerosos demócratas, tal alianza o convergencia no podía hacerse a cualquier precio:

"El Partido Democrático, adversario tenaz y resuelto del clericalismo, desea naturalmente, tal vez con más intensidad que los demás partidos liberales, la derrota del enemigo común; pero no la desea sacrificando platónicamente sus propias fuerzas en aras de los partidos liberales afines que no han sabido hasta aquí ni comprenderlo ni apreciarlo. Iría de seguro, si lo solicitan, a la unión con los partidos liberales para combatir al común adversario; pero irá sobre la base de la mutualidad más completa y equitativa" ${ }^{83}$.

Víctima de contradicciones de este tipo, la agrupación demócrata de Concepción fue una de las primeras en sufrir una severa división. A raíz de una elección de directorio ocurrida el 14 de julio de 1893, un grupo de militantes encabezado por José Bahamondes, Carlos Cid López y Nicanor M. Villarroel denunció la votación como "escandalosa", "a lo liberal radical", fruto de un "cambullón" en el que "muchos niños" repartieron votos previamente escritos o impresos, por lo que solicitó la anulación de la directiva elegida en aquella oportunidad y la convocatoria a nuevas elecciones ${ }^{84}$. Poco después este grupo -que declaraba contar con 73 militantes- radicalizó su postura, constituyéndose en "Agrupación Democrática Independiente de Concepción” y expulsó a los líderes de la fracción rival, la que, a su vez, adoptó la misma medida con los disidentes ${ }^{85}$. De esta manera, dos agrupaciones que reclamaban ser las auténticas representantes de "la Democracia" iniciaron una larga disputa en la ciudad penquista ${ }^{86}$. Los “demócratas independientes" publicaron el periódico El Demócrata, mientras que sus adversarios, encabezados por el concejal municipal Tomás Ríos Ovalle, que mantuvieron el nombre de demócratas a secas, continuaron expresándose a través de La Igualdad. Desde las páginas de este periódico se acentuó la crítica al gobierno de Montt, fruto de la desilusión por los resultados de la "revolución" de 1891. La escisión se extendió a la agrupación partidaria del vecino puerto de Talcahuano, donde también surgió un grupo de "demócratas independientes", que justificó su nacimiento con críticas políticas un poco más claras, acusando al grupo rival de

82 "Nota", El Demócrata, Rengo, 24 de agosto de 1893.

83 "Actualidad: la situación política. El Partido Democrático (De La Actualidad del 2)", El Ciudadano, Limache, 30 de noviembre de 1893.

84 "Remitidos", La Igualdad, Concepción, 22 de julio de 1893; "Protesta", El Demócrata, Concepción, 26 de agosto de 1893.

85 "Manifiesto del Directorio de la agrupación democrática de Concepción", La Igualdad, Concepción, 17 de agosto de 1893; “¿Qué pretende?” y “Acta de espulsión”, El Demócrata, Concepción, 26 de agosto de 1893.

${ }^{86}$ Más antecedentes sobre esta escisión pueden encontrarse en los siguientes artículos de la fracción demócrata "a secas": "La asamblea del domingo" y "Crónica", La Igualdad, Concepción, 3 de agosto de 1893; "Los disidentes" y "Crónica. Asamblea democrática", La Igualdad, Concepción, 17 de agosto de 1893; "Un manifiesto que manifiesta el despecho de su autor", La Igualdad, Concepción, 25 de agosto de 1893. 
haber ayudado con los votos de sus concejales a gravar al pueblo con fuertes contribuciones y tratar de asegurar su elección en los puestos dirigentes por medio de fraudes, al igual que en Concepción. Pero más sustancioso era el argumento final de los "independientes" de Talcahuano, puesto que anunciaba lo que sería, en definitiva, su principal caballo de batalla: la política de alianzas. Según este grupo, las circunstancias hacían necesaria la unión para combatir al enemigo que quería invadir el poder, y "sostener al actual gobierno en caso que lo necesite" 87.

Los oficialistas penquistas, por su parte, sin negar su eventual concurso al liberalismo para hacer frente al peligro conservador, ponían un mayor acento en la necesaria autonomía del partido:

"De dos males el menor. Por eso aceptamos al gobierno liberal a pesar de todos sus vicios.

Pero que este gobierno nos deje libres en el ejercicio de nuestros derechos si quiere nuestro concurso.

Que nos asegure la representación que nos corresponde en los diferentes cuerpos colegiados de la nación si quiere aprovecharse de una gran parte de nuestra fuerza electoral.

Si así no lo hace, se expone a que el pueblo, cansado de los cuervos y los vampiros, se lance solo a la lucha en legítima defensa de sus derechos y libertades" ${ }^{\prime 8}$.

Los "demócratas independientes" no lograron el apoyo del Directorio General demócrata. Sus argumentos pesaron menos que la aún bastante arraigada idea de la autonomía partidaria y la poderosa influencia de Tomás Ríos Ovalle, dirigente nacional desde los años previos a la guerra civil. La reclamación de los contestatarios penquistas fue desestimada por el Directorio General del partido, que apoyó a la directiva de la agrupación de Concepción encabezada por Ríos Ovalle ${ }^{89}$. Pero los problemas suscitados por esta división continuaron hasta por lo menos 1895, ya que los críticos del grupo oficialista penquista volvieron a la carga nuevamente en mayo de ese año, con una nueva - pero al parecer muy efímera- publicación, El Derecho, cuyo objetivo proclamado era "sostener hasta el último momento el estandarte sin mácula de la democracia", para ser un portavoz "no de un partidismo bien o mal fundado, sino de los obreros como igualmente de los desheredados de la fortuna" 90 .

En la perspectiva de las elecciones de marzo de 1894, la Convención Extraordinaria Demócrata, realizada en Santiago el 23 de diciembre de $1893^{91}$, zanjó, en principio, la cuestión de las alianzas, negando de manera tajante cualquier posibilidad de

87 "Proclama", El Demócrata, Concepción, 9 de septiembre de 1893. El destacado es nuestro. La versión del sector demócrata oficialista de este puerto se encuentra en "Talcahuano", La Igualdad, Concepción, 16 de septiembre de 1893.

${ }_{88}$ Jorje Roque, "El Cuco", La Igualdad, Concepción, 18 de noviembre de 1893.

89 "Circular del Directorio General del Partido Democrático", La Igualdad, Concepción, 9 de diciembre de 1893.

90 "Explicación necesaria", El Derecho, Concepción, 26 de mayo de 1895.

91 Esta convención fue convocada por iniciativa de la agrupación de Santiago, en virtud de la disposición estatutaria que preveía la posibilidad de que al menos seis agrupaciones solicitaran al Directorio General la reunión extraordinaria de la máxima instancia partidaria. "Crónica. Asamblea", $L a$ Igualdad, Concepción, 4 de noviembre de 1893. 
llegar a un pacto, acuerdo o unión con otras fuerzas políticas, al acordar "mantener incólume la autonomía e independencia" del partido y declarar que los gobiernos de coalición entre partidos de ideas antagónicas eran "un peligro para las instituciones democráticas y una amenaza a la libre manifestación de la soberanía nacional":

\begin{abstract}
"Mientras se mantenga un régimen de coalición que entrega al conservadurismo el gobierno del país, y que por lo tanto no da garantías de respeto al derecho electoral, mientras no se sustituya la política de terror y de opresión por actos de respeto al derecho de concordia y armonía social; mientras se mantenga la intranquilidad y zozobras públicas con amenazas de nuevas persecuciones y de complots fraguados para justificarlas; mientras se hambree al pueblo, se siembre la miseria en los hogares y no se reaccione contra esta política de peculados, de fraudes y de negociados escandalosos que llevan al país al borde de la ruina, el Partido Democrático asume una actitud de franca y enérgica oposición a semejante política, y combatirá sin tregua ni descanso, dentro de la Constitución y de la Ley, por devolver al país el sagrado depósito de su prosperidad y de sus libertades"92.
\end{abstract}

En conformidad con esta declaración de principios, el Directorio General demócrata reiteró que el partido iría solo a las elecciones de marzo de 1894 y que las agrupaciones, cualquiera fuera el número de sus miembros y las esperanzas de éxito, deberían llevar sus propios candidatos a municipales, diputados y senadores, sin prestar ninguna ayuda a los candidatos de otros partidos ${ }^{93}$. Ángel Guarello fue elegido diputado por Valparaíso y Casablanca. Por primera vez un demócrata llegaba al Parlamento.

El asunto de las alianzas y relaciones con otras fuerzas políticas se entremezclaba con las ambiciones personales que surgían en los caudillos locales y nacionales de "la Democracia". La aspiración a ser concejal municipal, diputado o senador podía ser explotada por otras fuerzas para atraer al PD o a algunos de sus líderes para concluir pactos electorales. Bajando en la jerarquía de sus afiliados, las "traiciones" inducidas por las otras fuerzas rivales podían estar motivadas por razones más prosaicas, como el cohecho descarado, la promesa de alguna prebenda o la falta de confianza en las propias fuerzas. De este modo, varios de los fracasos electorales del PD en los comicios de marzo de 1894 (exceptuando el mencionado triunfo de Guarello) fueron explicados por sus integrantes como productos de estas "traiciones" y manipulaciones de los partidos rivales ${ }^{94}$.

A pesar de que la Convención Extraordinaria de fines de 1893 se negó terminantemente a implementar una política de alianzas con otras fuerzas políticas de sesgo liberal, el tema seguía provocando serias contradicciones en la organización demó-

92 "La Gran Convención Democrática. Notables conclusiones", El Deber, Melipilla, 30 de diciembre de 1893; "Convención democrática", La Igualdad, Concepción, 19 de enero de 1894.

${ }^{93}$ Manuel Serei y Anjel Guarello, "Circular del Directorio Jeneral”, La Justicia, Talcahuano, 15 de febrero de 1894.

94 Véanse, a modo de ejemplo, las explicaciones de Enrique E. Soto, presidente de la agrupación demócrata de la $8^{\mathrm{a}}$ comuna santiaguina, de las causas del fracaso del candidato municipal de su partido en 1895. "Memoria que el presidente de la Octava Comuna del Partido Democrático presenta a la asamblea a nombre del directorio", La Igualdad, Santiago, 18 de mayo de 1895. 
crata. Esto era posible de apreciar incluso en un mismo órgano partidario. Así aparecían posiciones, como la del editorialista de La Igualdad, quien el 10 de octubre de 1894 proclamaba "la necesidad imprescindible que hay en aunar todas las fuerzas sanas del liberalismo, para de este modo, hacer fructífera y eficaz la labor del ministerio presidido por el honorable señor Mac-Iver", oponiéndose a las tentativas del "círculo monttino clerical" de derribarlo ${ }^{95}$. Estas afirmaciones eran contestadas indirectamente por declaraciones, como la formulada en una misiva del dirigente Juan de D. Leyton dirigida a los correligionarios del ministro recién aludido:

“¡Ah radicales! No esperéis que los demócratas os apoyemos en vuestra política aunque sea liberal. Ya la conocemos; está basada en las teorías de Voltaire, quien tuvo talento para derribar la torre de mentiras edificada en el transcurso de muchos siglos por la astucia frailuna; pero no tuvo el talento necesario para matar en su propio corazón el necio y vano orgullo que le dominó, del cual habéis, vosotros sus discípulos, heredado primorosamente. Los obreros no tenemos nada que esperar de vosotros, porque sois tan embusteros como los frailes, con cuya comparación me desquito ya que es la mayor ofensa que os pueda hacer" $"$.

Y mientras tanto, Ángel Guarello, el único diputado demócrata, optaba por apoyar al ministerio de tendencia liberal, formado después de las elecciones de marzo de 1894. Un par de años más tarde, ante una convención del partido, Guarello explicaría sin vacilaciones su posición:

"La organización de un Ministerio que siendo garantía para los partidos políticos, pusiera fin a las disidencias de la familia chilena, originando la guerra civil de 1891, se presentó como obra preferente a la mayoría de los grupos liberales que tenían representación en el Congreso Nacional.

Consultado por autorizados miembros de los partidos radical y liberal-democrático, no vacilé un solo instante en prestar el escaso contingente de mi voto a la organización de un ministerio radical-liberal que, sirviendo aquellos propósitos, realizara también una de las más importantes declaraciones de la Convención Democrática de Santiago, que condenó el régimen de fuerza y la coalición de partidos antagónicos en principios y doctrinas, como una amenaza para las libertades públicas.

Otra actitud, ya de abstención o contraria a la expuesta, no habría guardado conformidad ni con las instrucciones ni con los anhelos manifestados en aquella Convención que todos los correligionarios teníamos obligación de acatar" ${ }^{97}$.

Y en agosto de 1895, cuando un nuevo "gabinete de opinión” (compuesto únicamente por ministros de las distintas ramas del liberalismo) había sucedido a uno de "administración" (de liberales con el concurso del Partido Conservador"), Malaquías Concha, uno de los líderes del PD más proclives a la política de alianzas, reiteró pú-

95 Editorial, La Igualdad, Santiago, 20 de octubre de 1894.

96 "Solicitada" [Carta de Juan de Dios Leiton], La Igualdad, Santiago, 17 de noviembre de 1894.

97 "Memoria leída por el señor Anjel Guarello en la sesión de la Convención Democrática verificada el 17 de Julio de 1895", La Democracia, Santiago, 30 de julio de 1895. 
blicamente su disposición a apoyar e integrar el campo liberal, señalando que los demócratas aplaudían al ministerio liberal "por el hecho de serlo" y lo apoyarían, pero señalarían sus omisiones y fijarían "los rumbos que señalan las aspiraciones populares, para que sean corregidas aquellas y consultados estos en los consejos del nuevo Gabinete" ${ }^{98}$. Estas declaraciones significaban que el partido estaba disponible para apoyar a cualquier ministerio de signo exclusivamente liberal que no integrara ni a los conservadores ni a los nacionales o monttvaristas y, en una perspectiva de más largo plazo, equivalía a revelar su intención de sumarse a una alianza o frente liberal.

\section{LA UNIDAD Y LA EXPANSIÓN DESDE CENTROS DISPERSOS}

La recomposición de la unidad del PD no solo fue lenta y difícil. También transitó por senderos que probablemente sus principales líderes no previeron. Las sucesivas convenciones que se realizaron a partir de 1892 y hasta mediados de esa década no dieron, como es sabido, los frutos deseados; y la unidad siempre fue una construcción frágil, a veces puramente teórica. Como no era posible concretar la unificación a través de un acto único y centralizado, distintos segmentos del partido, especialmente sus bases obreras y artesanales, recorrieron un camino propio, apuntando a la unidad en sus localidades, construyendo su fuerza en relación con las organizaciones populares y participando en las elecciones municipales ${ }^{99}$. Agrupaciones como la de Valparaíso se consolidaron y no sufrieron mayores divisiones durante estos años ${ }^{100}$. Algunas, como la iquiqueña, se reunificaron rápidamente en $1892 \mathrm{y}$, aunque obtuvieron tempranamente algunos éxitos, adolecieron de una debilidad crónica que les impidió durante bastante tiempo pesar significativamente en la política local ${ }^{101}$. Otras, como la capitalina, debieron enfrentar situaciones más complejas.

En Santiago, la reconstrucción partidaria siguió un camino zigzagueante, en el que se combinaron los esfuerzos de la militancia de base y los estímulos de la dirección nacional del partido. Recién en junio de 1893, más de seis meses después de realizada la Convención de Parral, sus acuerdos se hicieron efectivos en la capital, al

98 M. Concha, “Unificación liberal”, La Democracia, Santiago, 13 de agosto de 1895.

99 Hacia 1893, la representación demócrata en algunas grandes municipalidades era significativa: cuatro concejales en Iquique, seis en Concepción y dos en Valparaíso. "Asuntos de Iquique", La Igualdad, Concepción, 24 de junio de 1893; Hijo del Pueblo, “Ayer y mañana”, La Igualdad, Concepción, 2 de septiembre de 1893; María Angélica Illanes, "El fruto prohibido de la guerra civil: el pueblo como poder. Valparaíso, 1891-1897”, María Angélica Illanes, Chile Des-centrado. Formación socio-cultural republicana y transición capitalista (1810-1910), Santiago, Lom Ediciones, 2004, 467.

${ }^{100}$ Una de las pocas voces disidentes de la posición mayoritariamente partidaria del bando congresista en la agrupación porteña, durante la guerra civil, había sido la de uno de sus fundadores, el médico Francisco Galleguillos Lorca. Véase el artículo de crítica a Galleguillos publicado en el periódico del sector mayoritario: "Crónica. Rectificamos", El Pueblo, Valparaíso, 9 de enero de 1892.

101 Pinto Vallejos, “Cuestión social o cuestión política?...”, op. cit., 271 y siguientes. Este autor demuestra el poco éxito electoral de los demócratas iquiqueños a lo largo de la década de 1890. Sin embargo, no menciona la existencia de cuatro concejales municipales de este partido (Juan D. R. Arellano, Federico González, Benigno Salas y Abelardo Verdugo) durante el período anterior a las elecciones de 1894. "Asuntos de Iquique", op. cit. 
elegirse un directorio común de las dos fracciones demócratas que se habían mantenido separadas desde la guerra civil ${ }^{102}$. Este directorio intentó desarrollar una política basada en la crítica a la conducción económica de la nación por parte de las élites dominantes. Las críticas a la llamada "Ley de Conversión", la estagnación industrial y la miseria de los trabajadores fueron los principales elementos del discurso del núcleo dirigente de los demócratas santiaguinos, sintetizado en un manifiesto dado a conocer en los primeros días de $1894^{103}$.

A pesar de estos y otros esfuerzos desarrollados por la primera directiva santiaguina "reunificada" - entre otros, la proclamación de diez candidatos a concejales municipales en febrero de $1894^{104}$, , el repunte efectivo de "la Democracia" en Santiago empezó a producirse poco después, gracias a las iniciativas del núcleo de militantes organizados en torno al periódico La Igualdad y a la Confederación Obrera de Sociedades Unidas. Su semanario fue, en los hechos, la voz del partido en la capital. Entre 1894 y 1896 este grupo encabezado por el tipógrafo Hipólito Olivares Mesa (antiguo editor de periódicos populares) y su hijo J. Gregorio Olivares, también tipógrafo y editor, Luis Bartolomé Díaz, quien sería a poco andar presidente de la Confederación Obrera, Juan Francisco González y otros militantes, dinamizó la vida partidaria fustigando la inercia y el oportunismo en las filas demócratas y estableciendo una fluida relación con las asociaciones populares y la Confederación Obrera.

Desde fines de agosto de 1894 apareció La Igualdad, autodefinido como "periódico obrero semanal". Su diagnóstico sobre la situación del partido era severo:

"El Directorio de la Agrupación de Santiago duerme; los directorios comunales no se sabe si existen o no; los nuevos registros del Partido todavía no se pueden abrir; los correligionarios no tienen un lugar donde reunirse para deliberar y ponerse de acuerdo sobre la marcha del Partido. En una palabra, no se toma medida alguna para que el entusiasmo no decaiga.

¿Qué es lo que se espera? ¿Trabajar cuando las elecciones estén encima? Es decir, ¡cuando ya no hay remedio!"’05.

Este grupo apostó a la solución de la crisis a través del reforzamiento de sus lazos con el mundo de los trabajadores. La Igualdad emuló la labor que en la década anterior habían realizado periódicos como El Precursor, La Razón, El Guttenberg, El Hijo del Pueblo, La Voz de la Democracia (Valparaíso) y su homónimo publicado entre 1885 y 1887 en la capital ${ }^{106}$, estimulando la convergencia social y política de

102 "Crónica. La Agrupación Democrática de Santiago", La Igualdad, Concepción, 10 de junio de 1893; “¡Ya estamos!”, La Igualdad, Concepción, 17 de junio de 1893. El directorio santiaguino quedó compuesto como sigue: presidente, Moisés González; vicepresidente, Victorino Stella; secretarios, Francisco Vargas Lazo e Ismael Arriaza; directores, Francisco Landa Z., Anacleto Olivares, Genaro Alarcón, Adolfo Fortin, Juan Segundo Burgos y Diego Escanilla.

103 "Manifiesto del Directorio de la Agrupación Democrática de Santiago a sus correlijionarios del departamento", La Igualdad, Concepción, 19 de enero de 1894.

104 "Agrupación democrática de Santiago", La Justicia, Talcahuano, 22 de febrero de 1894.

105 Muchos demócratas, “¿Dormimos?”, La Igualdad, Santiago, 22 de agosto de 1894.

106 Sobre la labor realizada por estos periódicos, véase Grez, De la “regeneración del pueblo”..., op. cit., 627-639 y 655-659. 
los trabajadores. Desde las páginas de La Igualdad se lanzó y difundió la idea de la creación de una "Confederación Obrera de las Sociedades Unidas" que reuniera todas las organizaciones populares santiaguinas ${ }^{107}$. En la concepción de uno de los redactores de La Igualdad que publicaba sus artículos bajo el seudónimo de Camilo Desmoulins $^{108}$, la constitución de la Confederación Obrera, el 23 de septiembre de 1894 , tenía por objetivo no solo hacer frente a las necesidades de la vida -tal como lo habían practicado tradicionalmente las sociedades mutualistas-, "sino también al avance solapado y el despotismo de los explotadores de la clase trabajadora"109. La ayuda mutua y la lucha reivindicativa, del mismo modo que lo social y lo político, se entroncaban en este discurso, anunciando una radicalización en el seno de la corriente demócrata que cobraría más vuelo en los años siguientes. "Si hoy tenemos un gran Partido político -vaticinaba este émulo criollo del revolucionario francés- mañana veremos levantarse toda una falange de trabajadores, sin distinción de gremios, obedeciendo a un solo pensamiento a una sola idea socialista, en bien de su progreso moral y material" $" 110$.

Y poco después, otro de los redactores del periódico continuaba fustigando la inercia y letargo de su partido, satisfecho, al parecer, con la elección de unos pocos municipales en algunos puntos del país. Se acercaban las elecciones y -según este militante- el directorio del partido en la capital aún no tomaba las medidas necesarias para convocar a sus militantes y simpatizantes ${ }^{111}$. Pero también estos demócratas intentaban sacudir a sus compañeros de base para que tomaran parte activa en la política comunal, asistiendo, por ejemplo, a las asambleas de electores municipales para impedir la adopción de medidas antipopulares ${ }^{112}$.

La crítica a los dirigentes era dura. Afirmaciones como "la Agrupación Democrática de Santiago parece que está muerta pues hasta ahora no da señales de vida. Estamos por creer que ese Directorio desea la muerte del Partido"113, se sostenía en denuncias más precisas y graves, como la formulada en la carta enviada al periódico por Gabriel del Campo, militante de la $10^{\mathrm{a}}$ comuna de Santiago, quien, a propósito de las elecciones de marzo de 1894, sostenía que el Directorio Central de la agrupación capitalina dormía "el sueño de los justos" y que lo mismo ocurría con los directorios comunales, exceptuando el de la $4^{\mathrm{a}}$ comuna. Pero más grave que la desidia eran las

107 "Bella idea", La Igualdad, Santiago, 2 de septiembre de 1894; "Un paso mas!", La Igualdad, Santiago, 8 de septiembre de 1894; "A los amigos del bien" y [Editorial], La Igualdad, Santiago, 22 de septiembre de 1894; [Editorial] y "Sociedades", La Igualdad, Santiago, 29 de septiembre de 1894; “Confederación Obrera”, La Igualdad, Santiago, 6 de octubre de 1894.

108 Camile Desmoulins (1760-1794), notable periodista y agitador de destacada participación en la Revolución Francesa. Fue diputado por París en la Convención Nacional, apoyó la sentencia de muerte de Luis XVI y se caracterizó por ser uno de los más fervientes detractores de los girondinos. Al escindirse, a comienzos de 1794, el bando de la Montaña, al que él pertenecía, formó junto con Danton la tendencia denominada de "los Indulgentes". Danton, Desmoulins y varios de sus partidarios fueron arrestados por orden de Robespierre, condenados a muerte en juicio sumario y guillotinados.

109 Camilo Desmoulins, "Al galope", La Igualdad, Santiago, 6 de octubre de 1894.

110 Idem

111 "Actualidad", La Igualdad, Santiago, 13 de octubre de 1894.

112 "Sacudamos la inercia", La Igualdad, Santiago, 20 de octubre de 1894.

113 "A todos lados", La Igualdad, Santiago, 10 de noviembre de 1894. 
acusaciones de oportunismo contra varios dirigentes de la $10^{\mathrm{a}}$ comuna, del mismo tipo de otras que por estos años comenzaban a abundar en el seno del partido ${ }^{114}$.

El grupo constituido en torno a La Igualdad obtuvo, hacia fines de 1894, la mayoría de los puestos del directorio de la agrupación partidaria santiaguina. Si bien Malaquías Concha resultó elegido presidente, cargo en el que se mantuvo solo tres meses, la vicepresidencia recayó en Luis B. Díaz, máximo líder de la Confederación Obrera, los puestos de secretarios en Juan F. González, secretario del organismo confederal, y Manuel Escudero, sobresaliendo entre los directores Hipólito Olivares, editor de La Igualdad ${ }^{115}$.

A poco andar, luego de la renuncia de Malaquías Concha al puesto de presidente de la agrupación capitalina, el nuevo directorio lanzó un manifiesto. Su análisis de la historia del partido, en particular de la actitud asumida frente a la guerra civil, indicaba el deseo de estos dirigentes de dar por superada, de una vez por todas, las antiguas divisiones. Según su interpretación, el partido en tanto tal no había asumido una posición, solo lo habían hecho, a título personal, algunos de sus militantes. Por lo demás, "la revolución" no había tenido razón de ser. El pueblo nada había ganado, al contrario, su situación desde entonces se había agravado. De allí provenían la división interna y la derrota electoral de marzo de 1894. La "decadencia" de la Agrupación Central (o Directorio General) era el fruto de "la acción destructora de falsos demócratas que se concertaron" para combatir al candidato del partido ${ }^{116}$.

A pesar de la dispersión reinante, desde algunas agrupaciones se inició un proceso de expansión partidaria hacia localidades cercanas. Así, por ejemplo, dando cumplimiento a un acuerdo del Directorio General que mandaba crear agrupaciones demócratas en Coronel y Lota, la sección de Concepción, con el apoyo de sus homólogas de Talcahuano y Tomé, organizó en mayo de 1893 una gira política a esas localidades de la cuenca del carbón, constituyéndose a fines de ese mismo mes la agrupación de Coronel y a fines de agosto la de Lota $^{117}$. Poco después, a comienzos de septiembre de 1893, al calor de la campaña preparatoria de las elecciones de marzo del año siguiente, el directorio de la agrupación de Concepción logró organizar una nueva agrupación en Penco ${ }^{118}$.

En otras ciudades, como Antofagasta, el surgimiento del partido tuvo una génesis más endógena. En 1894 un puñado de personas sentó las bases de la organización en ese puerto nortino y empezó a realizar una esforzada labor de propaganda ${ }^{119}$.

En Valparaíso, la agrupación democrática se mantuvo unida, reforzó sus lazos tradicionales con las asociaciones populares -que en muchos casos eran dirigidas por mi-

114 "Solicitada" [Carta de Gabriel del Campo], La Igualdad, Santiago, 10 de noviembre de 1894.

115 "Partido Democrático", La Igualdad, Santiago, 29 de diciembre de 1894.

116 "Manifiesto del directorio de la Agrupación Democrática de Santiago", anexo a La Igualdad 33, Santiago, 13 de abril de 1895.

117 "Crónica. Jira política", La Igualdad, Concepción, 6 de mayo de 1893; "La Agrupación Democrática de Coronel”, La Igualdad, Concepción, 27 de mayo de 1893; "Crónica. Nueva agrupación democrática”, La Igualdad, Concepción, 2 de septiembre de 1893.

118 "Penco", La Igualdad, 9 de septiembre de 1893.

119 Clara Rosa de Veced, "Recuerdos del pasado. Lo que éramos y lo que somos. Lo que queríamos y lo que se ha obtenido en la provincia”, El Proletario, Tocopilla, 23 de marzo de 1922. 
litantes demócratas- y publicó, entre 1891 y 1898, el periódico El Pueblo, de notable consistencia por sus análisis y vínculos con el movimiento popular. Los demócratas de esta ciudad, sin cargar con divisiones significativas como la que afectó a sus correligionarios de la capital, pudieron abocarse desde temprana data, después de terminada la guerra civil, a reconstruir el partido, acumulando fuerza propia (recordemos que su dirigente Ángel Guarello fue el primer diputado elegido por el partido en todo el país), y así utilizar su capacidad de irradiación (especialmente al interior de la provincia y en el Norte Chico) para influir en el proceso nacional de reunificación de sus camaradas.

Desde comienzos de 1892, los demócratas porteños se dedicaron decididamente a fortalecer el movimiento popular y su propia organización partidaria, con un estilo muy parecido al que les había dado tan buenos frutos antes de la guerra civil. La primera manifestación de masas fue convocada para el 1 de mayo, con el fin de solicitar al gobierno protección para la industria nacional y rebaja del precio de ciertos pasajes de la Empresa del Ferrocarril Urbano, como reivindicaciones principales. Para amplificar su llamamiento, los dirigentes de la agrupación de Valparaíso intentaron asociarse a otras agrupaciones departamentales ${ }^{120}$. Meses más tarde, la agrupación porteña se ponía a la cabeza de un movimiento en contra de un proyecto de ley presentado por el ejecutivo al Congreso Nacional, que fijaba penas para quienes hubiesen "provocado, mantenido o intentado provocar una cesación concertada del trabajo" con el objetivo de modificar los salarios y a quienes, de palabra o por escrito, hubiesen intentado provocar o incitar dichos actos. Un meeting de protesta realizado en noviembre del mismo año rubricó la campaña de agitación popular ${ }^{121}$. Otro ámbito abordado fue la lucha contra la influencia clerical conservadora en los medios populares. Los demócratas disputaron los espacios y el predominio público a las organizaciones católicas que pretendían desarrollar su poder entre los trabajadores de Valparaíso, organizando duras protestas ante las manifestaciones de instituciones como la conservadora Unión Social Orden y Trabajo ${ }^{122}$.

Esta estrategia fue exitosa. Entre 1892 y 1895 la agrupación porteña tuvo un desarrollo significativo. En 1893 el partido eligió cuatro concejales municipales que lograron esbozar un pacto con sus colegas radicales y balmacedistas para dirigir conjuntamente la administración local. Aunque -como ocurriría a menudo- los volubles liberales-democráticos desecharon rápidamente el compromiso contraído, su firma era un indicio de la fuerza alcanzada por los demócratas ${ }^{123}$. Hacia 1895, la agrupación de Valparaíso aseguraba que su base estaba compuesta por varios centenares de adherentes activos ${ }^{124}$. La labor de los concejales demócratas, reforzada por la agita-

120 "Meeting democrático" y "Circular", El Pueblo, Valparaíso, 16 de abril de 1892. Véase también, "El meeting de mañana" y "Partido Democrático. Gran meeting el domingo $1^{\circ}$ de mayo, a las tres de la tarde, en la Plaza de la Justicia", El Pueblo, Valparaíso, 30 de abril de 1892; "Próximo meeting", El Demócrata, Concepción, 30 de abril de 1892.

121 "El meeting de ayer", El Mercurio, Valparaíso, 7 de noviembre de 1892.

122 "La gran vergüenza del domingo", La Unión, Valparaíso, 4 de septiembre de 1894.

123 "La fe política", La Democracia, Santiago, 25 de julio de 1895.

124 "Cuenta que los municipios demócratas presentan a la Agrupación de Valparaíso", El Pueblo, Valparaíso, 12 y 13 de julio de 1895. 
ción mantenida por El Pueblo y el trabajo de sus militantes en las asociaciones agrupadas en la Liga de Sociedades Obreras, contribuyó vigorosamente al fortalecimiento de los lazos del partido con los sectores populares. Aprovechando las disposiciones de la "ley de Comuna Autónoma", la agrupación porteña del PD impulsó la participación de los trabajadores en las "asambleas de electores", como forma de control popular del gobierno municipal, a la par que sus representantes en el municipio presentaban proyectos destinados a crear una caja de ahorros, un montepío municipal o casa de préstamo y a reglamentar las casa de prendas $^{125}$.

La fuerza alcanzada por los demócratas de Valparaíso puso a sus principales cuadros a la cabeza del partido a nivel nacional: Manuel Serey (presidente), Ángel Guarello (secretario) y Francisco Galleguillos Lorca (director) destacaron como las figuras más emblemáticas del Directorio General, que mantuvo un mínimo de unidad formal partidaria nacional entre 1892 y mediados de 1895. Los líderes porteños, convertidos en dirigentes nacionales, fueron los principales impulsores de campañas como las destinadas a derogar los estados de sitio que afectaron a algunas provincias en los años inmediatamente posteriores a la guerra civil y para exigir medidas proteccionistas y paliativas de la miseria que afectaba a los sectores populares, dotando así de elementos de política general a las aún poco estructuradas fuerzas demócratas $^{126}$. Ese directorio convocó a la convención que debía inaugurarse en Valparaíso el 14 de julio de 1895, fijando como tareas principales del evento la reforma del reglamento partidario, a fin de afianzar la unidad y disciplina, la centralización de la dirección partidaria y la definición de criterios para las relaciones con otras fuerzas políticas ${ }^{127}$.

La Convención de Valparaíso sancionó estas proposiciones. En aquella reunión se acordó luchar por mantener en toda su integridad la ley municipal, base para asegurar el "gobierno propio" de los pueblos, y centralizar el Directorio General del partido, no pudiendo formar parte de él sino personas con residencia en Santiago, además de otorgarle facultades para "poder pactar uniones de fuerza con otros partidos políticos" en acuerdo con las agrupaciones de la colectividad ${ }^{128}$. Como lo explicaría poco después la nueva directiva en un manifiesto dirigido a sus bases, el antiguo estatuto orgánico demócrata prohibía de un modo absoluto las alianzas o uniones de fuerza entre sus agrupaciones y otras entidades políticas, sin acuerdo expreso de la convención. Esta disposición había sido necesaria al comienzo, para afianzar la independencia del partido, pero después de ocho años de vida autónoma -estimaban los

125 Illanes, "El fruto prohibido de la guerra civil...", op. cit., 470-480.

126 Véase, a modo de ejemplo: Manuel Serey y Ángel Guarello, "Directorio General del Partido Democrático. Circular", La Igualdad, Concepción, 7 de octubre de 1893.

127 "Circular que el Directorio Jeneral del Partido Democrático envía a las agrupaciones departamentales", La Igualdad, Santiago, 22 de junio de 1895.

128 "Conclusiones de la Convención Reglamentaria del Partido Democrático", El Pueblo, Valparaíso, 19 de julio de 1895; "Convención Democrática", La Democracia, Santiago, 19 de julio de 1895; De Petris Giesen, op. cit., 10. La Convención de Valparaíso eligió siete directores generales: Donato Millán, Malaquías Concha, Moisés González, Francisco Landa, José Manuel Saldaña, Manuel Antonio Escudero y Francisco Vargas Lazo. Luego esos directores nombraron los distintos cargos, entre ellos, presidente del partido a Millán y vicepresidente a Concha. 
dirigentes - no entrañaba peligro suavizar la rigidez de aquella medida $\mathrm{y}$, en cambio, había "positiva conveniencia" en concurrir con las fuerzas partidarias a la solución de los graves problemas que afectaban a la República ${ }^{129}$. Era el comienzo del fin del aislacionismo político de los demócratas y un paso decisivo para su ingreso a la Alianza Liberal.

\section{LA DIFí́CIL INTEGRACIÓN A LA AlianZa LiBERAL}

La cercanía de la elección presidencial que debía realizarse en 1896 provocó, por primera vez, una verdadera disputa por el poder central de acuerdo con las nuevas reglas impuestas por la coalición vencedora en 1891, ya que el nuevo Presidente de la República no sería escogido como "candidato oficial" por su predecesor, sino a través de una competencia abierta entre los partidos. Para que el nuevo sistema electoral fuera independiente de la intervención gubernamental, se había aumentado la autonomía de las autoridades municipales, en quienes recaía la obligación de organizar los procesos electorales. Como ha subrayado J. Samuel Valenzuela, se pasó entonces de un sistema electoral administrado oficialmente a uno convertido en mercado electoral, en el que las organizaciones partidarias compiten por el voto. La ampliación de la competencia electoral dio un nuevo impulso a las luchas partidistas. Se hizo de rigor -señala el mismo autor- organizar grandes convenciones nacionales para decidir los programas y las candidaturas presidenciales, profundizando una práctica que se había inaugurado en la década de $1870^{130}$.

En 1896 la perspectiva de la elección presidencial produjo un realineamiento de las fuerzas políticas y la proliferación de iniciativas de las cúpulas partidarias para lograr acuerdos destinados al nombramiento de candidatos proclives a sus intereses. En el campo liberal, Eduardo Matte, Enrique Mac-Iver y Enrique Salvador Sanfuentes propusieron a sus partidos -Liberal Doctrinario, Radical y Liberal Democrático, respectivamente- la realización de una convención restringida para elegir un candidato común de las fuerzas liberales. En ella participarían solo personalidades políticamente experimentadas por haber sido ministros, parlamentarios, electores presidenciales, consejeros de Estado, dirigentes obreros, etc. El objetivo de esta convención elitista era la nominación de Vicente Reyes, quien, según el historiador Gonzalo Vial, "era un hombre prestigioso y capaz, pero retraído y reacio a publicitarse [...], un hombre de elite. Lo designaría una convención también de elite; correría peligro si ella se ampliaba, incluyendo elementos socialmente menos destacados" 131 .

Por esta misma razón, los demás candidatos liberales apostaban a la idea de una convención amplia, la que fue decidida en diciembre de 1895. Los liberales doctrinarios rompieron entonces con el Directorio Liberal, insistiendo en la fórmula

129 "Manifiesto. El Directorio Jeneral del Partido Democrático a las agrupaciones del país", La Democracia, Santiago, 4 de agosto de 1895.

${ }_{130}$ Valenzuela, "Origen...", op. cit., 21 y 22.

131 Vial, op. cit., II:212. Destacado en el original. 
previamente acordada, al igual como lo hicieron poco después las directivas de los radicales y liberales democráticos o balmacedistas. La disyuntiva provocó una división significativa al interior de los balmacedistas y el surgimiento de un grupo de descontentos en las filas radicales ${ }^{132}$.

Las maniobras desplegadas por las distintas facciones del liberalismo produjeron fuertes fricciones en el PD. Los liberales-democráticos reanudaron con mayor fuerza sus esfuerzos por atraer a los demócratas a una alianza facilitada por los acuerdos de la Convención de Valparaíso. Para ello iniciaron gestiones ante el Directorio General del PD e hicieron públicas alabanzas "para el joven y fuerte partido", que ya contaba con un diputado (Guarello) y 45 concejales municipales en distintas ciudades ${ }^{133}$.

Los demócratas tendían naturalmente a preferir una convención amplia de las fuerzas liberales, de las que siempre se habían sentido parte, en tanto expresión del liberalismo popular. Pero la proposición de una convención de este tipo, formulada por algunos políticos tradicionales, suscitaba sospechas, especialmente en la dirigencia media de "la Democracia", aquella que, como la santiaguina, tenía su principal base de apoyo en las organizaciones sociales populares y en la Confederación Obrera, su organismo coordinador. El llamamiento de liberales de la élite a los dirigentes de las organizaciones obreras para participar en una convención amplia causaba gran malestar a estos líderes demócratas, que veían en ello una maniobra para no reconocerle a su partido el carácter de representante político de los sectores populares. Según Manuel Escudero, tales cabecillas liberales incurrían en un gravísimo error o pretendían "engañar al pueblo presentándole bases de una convención democrática y popular que jamás puede verificarse", entre otras razones porque los estatutos que regían a las organizaciones sociales les prohibían inmiscuirse en tanto tales en cuestiones políticas o religiosas ${ }^{134}$. Para que la convención fuera amplia y democrática había que reconocer el papel del PD. Si se pretendía dar un carácter democrático a la convención -afirmó Escudero-, lo más equitativo y justo sería llamar a los presidentes y secretarios de las diferentes agrupaciones demócratas, que tenían representación en más de veinte municipios. Pero ello no ocurría porque el "simulacro de convención" liberal quería atraer mediante los engaños de la "política intrigante" a la "gran fuerza electoral que militaba en las sociedades obreras" 135 .

De acuerdo con este análisis, el núcleo demócrata santiaguino que se expresaba a través de La Igualdad propuso la realización de una asamblea alternativa, denominada "Convención Democrática". En ella participarían los directorios de las agrupaciones del PD; igual número de delegados nombrados por los grupos políticos afines (liberales) que adhirieran a la iniciativa; los directores de las sociedades industriales, "con expresa excepción de los de crédito, usura o agiotaje"; los dueños

132 Ibid., II:231 y 213

133 De Petris Giesen, op. cit., 17.

134 Manuel A. Escudero, "Campo libre. Partido Democrático. Cuarta Comuna (Estación)", La Igualdad, Santiago, 5 de octubre de 1895.

${ }^{135}$ Idem. Véase también otro artículo de este dirigente con similares ideas publicado en la misma fecha: Manuel A. Escudero, "Los obreros en la gran convención radical, liberal i democrática", $L a$ Democracia, Santiago, 5 de octubre de 1895. 
de fábrica, taller o industria y los jefes y maestros de dichos establecimientos; los dueños de casas comerciales que pagaran patente; los directorios de los clubs [sic] sociales; los poseedores de un título profesional y los bachilleres en humanidades; los autores de alguna obra literaria, científica o artística; los editores y redactores de todos los diarios y periódicos existentes en el país, "con exclusión de los conservadores y monttvaristas"; los directores de las corporaciones privadas en áreas tan diversas como letras, bellas artes, fomento, gimnasia, académicas, etc.; los capitanes, tenientes, alféreces, sargentos y cabos que habían servido en el Ejército hasta el 31 de diciembre de 1891; los concejales municipales y los ex concejales municipales; y los profesores y demás empleados de la instrucción primaria. Esta convención se reuniría el mismo día y a la misma hora en todas las capitales de provincia, bajo la presidencia del directorio local de la Agrupación Democrática respectiva ${ }^{136}$.

Si bien las bases sociales a las que se aspiraba convocar eran muy amplias -una suerte de frente social productivista-ilustrado de carácter liberal y democrático-, su supuesto político - la hegemonía previa del PD- era inaceptable para las demás fuerzas liberales, que ni siquiera estaban de acuerdo en incluir a dicho partido en una alianza bajo su propia dirección. La proposición emanada desde las páginas de $L a$ Igualdad no tenía ninguna posibilidad de prosperar. Solo podía ser entendida como una manera de aunar a los demócratas y realizar una labor pedagógica y de agitación en el seno de las sociedades obreras, que estaban siendo cortejadas por los políticos liberales partidarios de la "convención amplia" para designar el candidato presidencial. Para lograrlo, los políticos tradicionales disponían -como siempre- de sus propios militantes obreros. Hacia ellos debía, necesariamente, dirigirse la crítica de los demócratas:

"Pero os equivocáis en todo señores obreros de los partidos históricos, os condenamos porque con vuestra conducta reprensible desprestigiáis ante la opinión a los que con altiva independencia trabajan de su cuenta propia en beneficio de todos. ¿Quién medianamente piense comprende que solo formáis en los demás partidos, solo por vanidad, ignorancia y especulación?"137.

A la espera de una decantación de la situación, el Directorio General del PD publicó durante la primera quincena de noviembre de 1895 una circular dirigida a sus agrupaciones departamentales, instándolas a combatir el cohecho, multiplicar las organizaciones partidarias en distintos puntos del país y mantenerse a la expectativa, a la espera de una decisión que adoptaría salvaguardando la doctrina, la dignidad y la existencia del PD, amenazado más que nunca por sus adversarios. Mientras no llegara ese momento, por respeto a los principios y a la disciplina política, la directiva demócrata ordenó la más férrea abstención de todo compromiso individual con determinados candidatos. De acuerdo con esta línea, el Directorio General aseguró a sus correligionarios que mantenía una independencia absoluta, que ningún pacto,

136 "Convención Democrática", La Igualdad, Santiago, 14 de diciembre de 1895.

137 Milor, "El obrero fuera de la democracia", La Igualdad, Santiago, 14 de diciembre de 1895. 
compromiso o acuerdo lo ligaba con hombres, grupos o partidos, y que desautorizaba toda gestión o propaganda escrita o hablada dirigida a contraer compromisos anticipados o que tendiera a prestigiar candidaturas no designadas aún por la convención partidaria ${ }^{138}$.

En términos inmediatos, lo que estaba en juego para la joven fuerza política popular era su reconocimiento en tanto partido político y no mera "bandería", como lo había calificado un diputado conservador ${ }^{139}$.

Respondiendo a la creciente inquietud de sus bases, Donato Millán y Francisco Vargas Laso, presidente y secretario del Directorio General, respectivamente, despacharon a comienzos de enero de 1896 una circular a las agrupaciones departamentales demócratas, convocándolas a una convención que se realizaría el 15 de marzo, a fin de designar al candidato del partido a la Presidencia de la República. Junto con dar cuenta de un pacto concluido con un grupo balmacedista disidente, se reiteraba el llamamiento a otras tendencias liberales para participar en la magna asamblea que se preparaba para fines del verano, asegurando que "cualquiera otra fracción de filiación netamente liberal”, que se adhiriera a la Convención Democrática, hallaría "la franca y leal amistad" que estos sabían brindar a los que reconocían sus derechos y prerrogativas. La consulta a la opinión del país se haría por medio de un plebiscito tan amplio como lo permitieran las circunstancias, teniendo cabida en él "todas las legítimas aspiraciones, todos los elementos políticos sanos" que tuvieran afinidad o que aceptaran "los principios del Programa de la Democracia"140.

La agrupación santiaguina llamó a sus miembros a una gran asamblea en la que el Directorio General respondería las inquietudes de las bases ${ }^{141}$. Los dirigentes nacionales presentes en la reunión capitalina del 12 de enero -Francisco Landa, Malaquías Concha y Manuel Escudero- estuvieron en perfecta sintonía con los numerosos concurrentes, que acordaron rechazar cualquier alianza con los conservadores y monttvaristas. A nombre de la instancia superior del partido, Concha afirmó que aún no se habían establecido alianzas con nadie, sino un simple proyecto que debía ser aprobado o rechazado por la convención de marzo. Y para calmar la mayor de las inquietudes que surgían desde distintos puntos, afirmó de manera inequívoca: "No hemos proyectado ni proyectaremos nunca alianza con los conservadores ni con los monttvaristas porque son los eternos enemigos de la libertad y del pueblo"142. Para infundir mayor confianza, la asamblea acordó publicar un breve comunicado del mismo dirigente, en el que se afirmaba de forma taxativa: "Declaro que el partido se mantendrá incólume conservando su autonomía e independencia política sea

138 "Circular. El Directorio Jeneral del Partido Democrático a las agrupaciones departamentales", La Democracia, Santiago, 11 de noviembre de 1895.

139 Milor, "El Partido Democrático juzgado por un conservador", La Igualdad, Santiago, 9 de noviembre de 1895

140 "Partido Democrático. Convocatoria a una convención interna para el $1^{\circ}$ de marzo", $L a$ Democracia, Santiago, 10 de enero de 1896.

141 "Partido Democrático. Agrupación de Santiago", La Democracia, Santiago, 12 de enero de 1896.

142 "Partido Democrático. La gran asamblea del domingo", La Democracia, Santiago, 14 de enero de 1896. 
cual sea las vicisitudes porque atraviese: solo una convención interna del Partido podrá hacerle variar este rumbo que es una aspiración y un baluarte contra nuestros enemigos" $" 143$.

La "convención restringida" liberal del 30 de enero de 1896 designó, como estaba previsto, casi por unanimidad a Vicente Reyes como candidato presidencial ${ }^{144}$. Los demócratas, que no fueron invitados ${ }^{145}$, denunciaron una vez más su carácter oligárquico e insistieron en su convocatoria a una "convención democrática" en alianza con una fracción de los balmacedistas ${ }^{146}$, precedida por la realización de una "convención interna" de su propio partido ${ }^{147}$.

A esas alturas la tensión al interior del PD iba in crescendo. La agrupación santiaguina -uno de los principales focos de resistencia a la política de alianzas con fuerzas oligárquicas, incluso de tinte liberal- realizó una asamblea el 9 de febrero para designar a sus delegados a la convención partidaria de marzo, resultando elegidos Enrique Soto (dirigente de la Confederación Obrera) y Jacinto R. Valenzuela. Según informó El Mercurio, en aquella oportunidad la discusión política fue fuerte, formulándose cargos contra algunos miembros del partido que respondieron a sus acusadores. Como conclusión de las discusiones, se acordó considerar como único órgano oficial de la agrupación de Santiago al periódico La Igualdad; desautorizar la sección especial en que hasta ese momento se habían estado publicando las actas partidarias en un diario de la tarde; considerar traidor al partido, y por consiguiente expulsado de él, a quien publicara en cualquier otro diario ataques u ofensas contra los miembros de la agrupación; y nombrar una comisión para que investigara la conducta de tres militantes, a fin de decidir su expulsión "si resultaban culpables de los cargos que se les habían hecho"148.

Las medidas adoptadas por la asamblea santiaguina reflejaban la dura pugna que se libraba entre partidarios y adversarios de la alianza con las fuerzas del liberalismo oficial. La desautorización hecha a "un diario de la tarde" se refería al periódico $L a$ Democracia, que, aunque autodefinido como "independiente", actuaba en los hechos como un portavoz oficioso de la tendencia de Malaquías Concha, y a ese título se

143 "Partido Democrático. Agrupación de Santiago. Importante declaración del señor Malaquías Concha", La Democracia, Santiago, 15 de enero de 1896.

144 Vial, op. cit., II:213. "La Convención de ayer. Se proclama candidato al Sr. Vicente Reyes", La Democracia, Santiago, 31 de enero de 1896; Arturo Alessandri Palma, Recuerdos de juventud, Santiago, Academia Chilena de la Historia, 2009, 298.

${ }_{145}$ A mediados de octubre de 1895 ya se sabía que los comités de los partidos de la Alianza Liberal habían rechazado la participación del Partido Democrático en la Gran Convención. "Graves noticias. Proposiciones rechazadas en el seno de los comités políticos", La Democracia, Santiago, 13 de octubre de 1895.

${ }^{146}$ La alianza con una fracción del balmacedismo fue firmada un día antes de la Convención Liberal. "Crónica política", La Democracia, Santiago, 29 de enero de 1896.

147 Camilo Desmoulins, "Grandes i pequeños", La Igualdad, Santiago, 27 de febrero de 1896; "Ojalá se cumplan", La Igualdad, Santiago, 3 de febrero de 1896; "La próxima convención interna del Partido Democrático" y Manuel A. Escudero, "Inconsecuencia i deslealtad. Conveniencias políticas", $L a$ Igualdad, Santiago, 10 de febrero de 1896.

148 "Santiago. Partido Democrático", El Mercurio, Valparaíso, 12 de febrero de 1896. Véase también "Partido Democrático. La asamblea de ayer", La Igualdad, Santiago, 10 de febrero de 1896. 
manifestaba fervorosamente a favor de la integración de los demócratas a la Alianza Liberal. Y en sentido contrario, la declaración de La Igualdad como único órgano autorizado de la agrupación demócrata de la capital representaba una victoria táctica del sector aglutinado en torno a ese periódico, cuyas bases sociales se encontraban en la Confederación Obrera. La contradicción entre ambos grupos afloraba, a pesar de los esfuerzos por evitar una imagen pública de división. De este modo, al día siguiente de la asamblea, uno de los colaboradores de La Igualdad hizo un llamamiento a sus correligionarios para que apoyaran el periódico, proponiendo que los directorios comunales del partido en Santiago le aportaran una subvención, en vistas de que el Directorio General "poco o nada" se preocupaba por su suerte ${ }^{149}$.

Así planteadas las cosas, el sector mayoritario del Directorio General apostó a reforzar su influencia en las provincias. Las giras a diferentes puntos del país de ciertos dirigentes nacionales de la tendencia de Malaquías Concha desorientaron a algunos militantes e irritaron a los contestatarios ${ }^{150}$.

A pesar de que la convención demócrata de marzo ratificó la proyectada alianza con un sector de los balmacedistas ${ }^{151}$, muy rápidamente estos deshicieron su compromiso, ante la escasa perspectiva electoral que les brindaba el pacto. Así, los demócratas quedaron nuevamente solos ${ }^{152}$. La "convención liberal amplia" del 5 de abril -a la que se sumaron los efímeros aliados balmacedistas de los demócratas- eligió a Federico Errázuriz Echaurren como abanderado, quien obtuvo poco después el apoyo de los conservadores. De esta manera, la lucha presidencial quedó circunscrita a dos campos: la candidatura de Vicente Reyes, de marcado tinte anticlerical, y la de Federico Errázuriz, apoyado por varias fracciones del liberalismo y por el propio Partido Conservador ${ }^{153}$.

El PD resultó marginado de la lucha electoral. Descolocado por el brusco giro de los tornadizos socios balmacedistas, el Directorio General del partido dirigió una circular a sus bases explicándoles que la proyectada "convención democrática" ya no tenía sentido y que los esfuerzos de la colectividad debían dirigirse a obtener la mayor cantidad posible de electores a presidente, con férrea disciplina, evitando las disensiones o apoyos personales a los candidatos de los "partidos históricos"154.

Pero la disyuntiva planteada -Reyes o Errázuriz- llevó a la mayoría del Directorio General a optar por el apoyo a Reyes e ingresar a la Alianza Liberal para combatir al aliado de los conservadores. A comienzos de mayo, la Alianza comisionó a la misma fracción balmacedista que había sostenido una fugaz alianza con los demócra-

\footnotetext{
149 Andrés Acevedo, "Un deber que no se cumple", La Igualdad, Santiago, 10 de febrero de 1896.

150 "Partido Democrático", La Igualdad, Santiago, 24 de febrero de 1896; "Última hora. Asamblea democrática", La Igualdad, Santiago, 24 de febrero de 1896.

151 Eleodoro Estay, "La Convención interna del Partido Democrático", La Igualdad, Santiago, 28 de marzo de 1896.

152 "La Convención interna del Partido Democrático" y Manuel A. Escudero, "Ruptura con los liberales democráticos ibañistas. El quid de la cuestión", La Igualdad, Santiago, 28 de marzo de 1896; "Campo neutral. Ruptura de una alianza", La Democracia, Santiago, 31 de marzo de 1896.

153 Vial, op. cit., II:214-220.

154 "Circular. El Directorio Jeneral a las agrupaciones del Partido Democrático", La Democracia, Santiago, 9 de abril de 1896. También en La Igualdad, Santiago, 11 de abril de 1896.
} 
tas, para proponer a estos últimos su ingreso a la Alianza Liberal. Malaquías Concha y Francisco Landa fueron delegados por el Directorio General democrático para oír las proposiciones provenientes de los liberales "reyistas"155. En las bases del acuerdo concluido con los delegados de la Alianza Liberal (Guillermo Matta, Alejandro Fierro y Julio Bañados Espinoza), Concha y Landa declararon que aceptaban la promesa de los representantes de la Alianza de dar atención preferente a la promulgación de leyes sobre la industria nacional y de instrucción primaria, gratuita y obligatoria, para ambos sexos; al afianzamiento de la autonomía local; a la protección efectiva de los trabajadores; al mantenimiento de las leyes constitutivas del estado civil y al robustecimiento de la acción docente del Estado ${ }^{156}$. De acuerdo con un principio de igualdad esencial, el PD quedó representado en la Junta Central de la Alianza por tres miembros, del mismo modo que los demás partidos, previéndose que se le garantizaría una representación similar en las juntas locales del conglomerado aliancista ${ }^{157}$.

La decisión, ampliamente mayoritaria, de los dirigentes nacionales demócratas de ingresar al campo del liberalismo oficial suscitó un fuerte debate en las bases del partido. Desde las columnas de La Igualdad-que desde fines de enero se autodefinía como "periódico social-demócrata" y a partir de mayo como "demócrata-social"- se levantó una dura crítica a los miembros del Directorio General, exceptuando al anciano Donato Millán, único miembro de esa instancia que se oponía abiertamente a la repentina alianza:

“[...] nuestro partido entra de lleno a apoyar la candidatura de don Vicente Reyes, proclamada por la Alianza compuesta de los elementos políticos que más males han causado a nuestra causa y que el país entero repudia como malsanos y corrompidos, como malos gobernantes y enemigos declarados del pueblo.

¡Los hijos del pueblo, los explotados apoyando a los explotadores de su trabajo y de la honra nacional!

¡Los demócratas, tan celosos de su independencia, tan fieles guardianes de la bandera inmaculada que solo puede mantenerse pura y sin mancha en la autonomía renegando de ella y poniéndola a los pies de la oligarquía liberal!"158.

El compromiso suscrito por el Directorio General causó confusión entre los demócratas, ya que contrariaba los principios y declaraciones que muy poco antes habían formulado esos mismos dirigentes. Entre los opositores a este vuelco estratégico se destacaron los redactores de La Igualdad santiaguina, quienes, como corolario a sus críticas, levantaron la divisa de la "autonomía del pueblo"159. Otros, como los demócratas que publicaban El Pueblo en Valparaíso, también dieron a conocer su descontento, pero con un dejo mayor de resignación:

155 "Actualidad política. Acta de los acuerdos celebrados por los presidentes de la Alianza Liberal i del Partido Democrático", La Democracia, Santiago, 18 de mayo de 1896.

156 Citado por De Petris, op. cit., 19.

157 Idem.

158 "Hablemos claro I", La Igualdad, Santiago, 27 de mayo de 1896.

159 Idem. 
"Nos repugnan las alianzas, sean con quienes sean. Nunca hemos escrito una plumada en su favor, siempre en contra. Nos sometemos hoy en fuerza de la disciplina democrática; pero estamos dispuestos a quedarnos en nuestras casas y alejarnos momentánea y accidentalmente de las filas de un partido en el cual hemos empezado la azarosa vida política, si se nos obliga -aún por abrumadora mayoría- a votar juntos en listas donde al lado de un correligionario figure el nombre de otro ciudadano de extraño partido, cualquiera que sea su honorabilidad y antecedentes.

La disciplina podrá obligar al hombre a aceptar las resoluciones de mayoría, que son el lenguaje de las democracias; pero nunca se podrá invocar la disciplina en pro de un propósito que pugne con la razón constitutiva del principio político que sustenten y hayan prometido sustentar los partidarios de una causa regeneradora como es la democrática y enemiga, por tanto, de los crapulosos partidos militantes en la República.

Aceptamos en contra de nuestra voluntad la fusión liberal, que lo único que tiene de pasable, digámoslo así, es que ella facilita el combate en filas compactas con malos liberales hacia el entronizamiento [sic] del partido conservador, más -al menos en Valparaíso-, debemos ir a las urnas electorales por electores propios, si queremos conservar la moralidad política en nuestra agrupación"160.

El grupo dirigente, liderado por Malaquías Concha, logró imponer su política. La mayoría de las agrupaciones asumieron, si no con entusiasmo, al menos por acatamiento la nueva alianza. Una de ellas, la de San Felipe, a través de su órgano oficial expresó con convicción las tareas que la disciplina imponía, sosteniendo que había que probar, una vez más, a los liberales, que los demócratas jamás dejarían de combatir a los jesuitas y especuladores políticos que en abigarrado consorcio habían levantado a Federico Errázuriz, "como enseña viviente de un pasado sangriento y oprobioso". Los demócratas debían, pues, apoyar a Vicente Reyes, "por ser la encarnación elocuente de la probidad en las cuestiones políticas y económicas del país" ${ }^{161}$.

El entusiasmo electoral ganó a la mayoría del partido tras la idea de combatir al enemigo principal representado por el conservadurismo. Los contestatarios fueron aislados. En la asamblea realizada el 8 de junio en un teatro de Santiago, el tipógrafo Hipólito Olivares Mesa, editor de La Igualdad y ex director de la agrupación democrática de la capital, y su hijo Gregorio Olivares T., redactor de ese periódico y ex secretario de la misma agrupación partidaria, fueron acallados, impidiéndoles hacer sus descargos frente a la decisión de expulsarlos del partido. Un manifiesto de Donato Millán criticando la decisión adoptada por el resto del Directorio General tampoco fue dado a conocer ${ }^{162}$.

160 [Editorial], El Pueblo, Valparaíso, 27 de mayo de 1896.

161 Botón, “¡A la lucha!”, El Hijo del Pueblo, San Felipe, 31 de mayo de 1896. La agrupación sanfelipeña participó activamente en la campaña presidencial. Además de los trabajos de propaganda, una comisión compuesta por varios de sus dirigentes asistió a comienzos de 1897 a la Junta General de la Alianza Liberal, reunida en Santiago. Marianne Virginia Shaale Urbina, De agonías y luchas: una aproximación a la sociabilidad obrera, Tesis para optar al grado de Licenciada en Historia, Pontificia Universidad Católica de Chile, Santiago, 1997, 288 y 289.

162 Hipólito Olivares Mesa, J. Gregorio Olivares T. y Eleodoro Estay, "A nuestros amigos de Santiago", La Igualdad, Santiago, 19 de junio de 1896. 
La suerte estaba echada: el PD ingresaba a la Alianza Liberal, sepultando las aspiraciones de autonomía total de una gran parte de su base popular. Para reforzar su control del partido, la mayoría del Directorio General organizó varias giras a distintos puntos del país, entre ellas, una a la zona de Aconcagua y otra al sur. En junio Malaquías Concha y Francisco Galleguillos Lorca, presidente de la agrupación de Valparaíso, visitaron San Felipe y Los Andes, y luego el mismo Concha, acompañado de Artemio Gutiérrez, Alejandro Bustamante, Manuel Serey y otros dirigentes se dirigieron hacia el sur, teniendo como hito principal la ciudad de Concepción ${ }^{163}$. Entretanto, en Santiago este sector convocó a un meeting popular para el 12 de julio, a fin de denunciar "los fraudes escandalosos cometidos por la Coalición Conservadora en la elección presidencial" y supuestas intentonas golpistas de ese conglomerado. Al mismo tiempo, aportó un irrestricto apoyo a sus aliados liberales que se encontraban a la cabeza de los poderes Ejecutivo y Legislativo, y, uniendo las reivindicaciones sociales con la nueva opción política, el oficialismo demócrata exhortó al pueblo de Santiago:

“¡El país está cansado de politiqueros de pacotilla!

El pueblo siente hambre, quiere trabajo, industria, crédito, capitales para combatir la miseria, desterrar la ignorancia, procurar su bienestar y el engrandecimiento de la República.

El país repudia la política sectaria, detestan los partidos clericales que mezclan la religión con la política, está fatigado de esta eterna lucha por el cielo y el infierno, que siembra odios, que predica el exterminio y que trae la desunión de la familia, mientras golpea a la puerta de sus hogares con todo su cortejo de horrores, de crímenes y de inmoralidad la imagen espantable de la miseria.

Concurramos, pues, al meeting para significar al Senado de la República cuanto espera el pueblo de su probidad y de su justicia para corregir los abusos que falsean la elección y hacen rendir el debido homenaje a la soberanía popular, fuente sagrada de donde emana todo poder, toda autoridad en el seno de las Democracias" ${ }^{164}$.

En los meses siguientes, a la par que se afirmaba el grupo demócrata hegemónico, otros militantes destacados fueron marginados o expulsados del partido, a causa de su oposición o reticencias frente a la política de alianzas. Manuel A. Escudero, miembro del Directorio General, quien poco antes había dirigido un manifiesto a los demócratas declarando su "independencia" respecto de la nueva línea ${ }^{165}$, fue expulsado en octubre junto a los dirigentes de la Confederación Obrera Luis Bartolomé Díaz y Enrique E. Soto ${ }^{166}$. La asamblea de la agrupación santiaguina -ahora completamen-

163 "Jira política", El Hijo del Pueblo, San Felipe, 21 de junio de 1896; “Concepción. Recepción a los delegados del Directorio General del Partido Demócrata”, El Ferrocarril, Santiago, 29 de junio de 1896.

164 AHN, Fondo Intendencia de Santiago (en adelante FIS), vol. 155 (julio de 1896), "Partido Democrático. Agrupación de Santiago. Gran meeting", recorte de prensa sin referencia anexo al oficio sin número, y sin fecha dirigido al Intendente de Santiago, s.f. Nuestras cursivas corresponden a letras mayúsculas en el original.

165 Un demócrata, "Carta abierta al señor Manuel A. Escudero ¡Director General del Partido Democrático!", El Hijo del Pueblo, San Felipe, 3 de octubre de 1896.

166 Luis Bartolomé Díaz reingresó posteriormente al Partido Democrático, incorporándose a la fracción doctrinaria. 
te controlada por el sector de Malaquías Concha y Artemio Gutiérrez- incluyó en la fórmula de expulsión de Escudero, Díaz y Soto "a los demás correligionarios que les acompañen", pero dándoles "plazo hasta después de la convención que tenga el partido, para que se rehabiliten si es que lo deseen"167. Luis B. Díaz, Juan de Dios Lobos y Pedro M. Aliaga intentaron convocar a los presidentes de las agrupaciones demócratas a una reunión alternativa a la convención "espuria" llamada por el Directorio General para el 20 de noviembre ${ }^{168}$.

A pesar de sus esfuerzos los disidentes fueron aislados: el Directorio General los calificó de "unos cuantos individuos anónimos" que, atribuyéndose la representación de la Agrupación de Santiago, habían recurrido a "artimañas, sugeridas por los enemigos de la Democracia, a cerebros desequilibrados que obran por la pasión o la necesidad", y mantuvo su convocatoria para el 20 de noviembre ${ }^{169}$.

La designación hecha por el Congreso Pleno el 3 de septiembre de 1896 de Federico Errázuriz Zañartu como vencedor de la elección presidencial había significado un duro golpe para la Alianza Liberal y para el $\mathrm{PD}^{170}$. Este último sufrió la derrota tal vez más que sus socios, ya que, como señalaba El Roto, órgano de los demócratas de Cauquenes, aparte de las disensiones internas, los militantes de este partido habían sacrificado su única riqueza, "el tiempo, con el que nos ganamos el sustento diario, y que a un demócrata más que a nadie le hace falta" ${ }^{171}$. Además, los demócratas aún poco duchos en las artimañas de la política, sufrieron los embates de sus aliados, que pretendían reducirlos al simple papel de figurantes. A pesar de la desilusión, la mayoría de los demócratas en todo el país, alineada tras la dirección de su partido, luego de denunciar distintos vicios de procedimiento por parte de la mayoría parlamentaria, optó por resignarse y renovar su compromiso con el frente unido del liberalismo en la perspectiva de las elecciones generales de marzo de 1897. Incluso antes de que el Directorio General enviara instrucciones a los directorios provinciales, agrupaciones como la de Concepción renovaron sus votos de fidelidad con el campo liberal. La Alianza Liberal -se leía en el periódico demócrata penquista a comienzos de septiembre de 1896- debía seguir impertérrita, hasta afianzar sólidamente la bandera que encarnaba la causa del liberalismo, que tan patrióticamente había sido defendida en las urnas del 25 de junio ${ }^{172}$.

Este compromiso se desprendía de la identificación que, desde su fundación a fines de 1887, el PD había mantenido con el liberalismo, considerándose a sí mismo como la rama más consecuente y radical de la "gran familia liberal". El liberalismo popular seguía siendo el sello político de este partido, por lo que, a pesar de las

167 "Partido democrático", El Hijo del Pueblo, San Felipe, 17 de octubre de 1896.

168 "Partido Democrático. Circular", El Trabajo, Concepción, 6 de noviembre de 1896.

169 La convocatoria original se encuentra en "Convención democrática", El Mercurio de Valparaíso, Valparaíso, 14 de octubre de 1896. La reafirmación de este llamado en: "Circular del Partido Democrático", El Hijo del Pueblo, San Felipe, 23 de noviembre de 1896.

170 Vial, op. cit., vol. II, 222-226. Véanse, a título ilustrativo de la frustración e impotencia de los demócratas, los siguientes artículos de prensa: "Más pudo el oro que la razón", El Hijo del Pueblo, San Felipe, 6 de septiembre de 1896; "El desenlace", El Trabajo, Concepción, 7 de septiembre de 1896.

171 "El Roto. Nuestro propósito", El Roto, Cauquenes, 25 de octubre de 1896.

172 "El desenlace", op. cit. 
claudicaciones, inconsecuencias y hasta traiciones de sus aliados, los demócratas persistían en buscar el entendimiento con las distintas ramas del liberalismo nacional. Como lo expresara Francisco Galleguillos Lorca, fundador del PD y delegado de Valparaíso en la sesión inaugural de la convención del 20 de noviembre, este sentimiento se traducía en la divisa: "Guerra eterna al clericalismo y triunfo completo al liberalismo chileno" "173. Así lo pensaban también los demócratas penquistas que editaban El Trabajo, quienes luego de la derrota de Vicente Reyes continuaban reafirmando su compromiso con la causa liberal:

"Nacimos al mundo político proclamando el credo Liberal y caeremos envuelto en nuestro estandarte sin abjurar un ápice de nuestras convicciones, y el último grito que exhalaremos en el lecho de muerte será el amor más puro a esas doctrinas, que tan grande y próspera hicieron a nuestra Patria en 35 años de gobierno"174.

Las esperanzas de la mayoría demócrata que había optado por esta línea de conducta se vieron reforzadas cuando el Directorio General del partido, en un manifiesto dirigido a sus bases en octubre de 1896, persistió en su opción aliancista, haciendo un llamado para lograr la "reconciliación franca y abierta de todas las fracciones, hombres o partidos de filiación netamente liberal", para constituir un poderoso partido de gobierno. En esa estrategia, correspondía al PD:

"[...] tender puente de oro a las distintas fracciones del liberalismo para estrecharlas en común abrazo de fraternidad, para invitarlos a deponer en el altar de la patria los resentimientos o pasiones que los dividen y reconstituyan más vigoroso, más lozano y más unido que antes el viejo y glorioso partido liberal apoyado esta vez en los robustos brazos y generosos pechos del pueblo"175.

La identificación del PD con la "familia liberal" era total. Tal vez nunca antes en sus nueve años de vida esta colectividad había proclamado con tanta claridad su afán de ser el motor que llevara a la regeneración y refundación del viejo Partido Liberal. El llamado de los dirigentes demócratas parecía ser sincero, ¿pero lograría ser escuchado por sus destinatarios del "liberalismo de frac y corbata"?

\section{LAS ELECCIONES DE MARZO DE 1897}

Los partidos tradicionales de la Alianza Liberal veían al PD como un socio menor, destinado a aportar un nada despreciable caudal de votos populares al con-

173 "Discurso del delegado por Valparaíso don Francisco Galleguillos Lorca, pronunciado en la sesión inaugural de la Convención del Partido Democrático celebrada el 20 de noviembre", El Hijo del Pueblo, San Felipe, 5 de diciembre de 1896.

174 "El desenlace", op. cit.

175 "Manifiesto del Directorio General a las agrupaciones del Partido Democrático", El Trabajo, Concepción, 20 de octubre de 1896 
glomerado ${ }^{176}$, pero no estaban dispuestos a concederle las posiciones a las que esta colectividad creía que, con legítimo derecho, poder aspirar. Es por eso que desde un comienzo las relaciones entre ellos estuvieron plagadas de dificultades, siendo el centro de las disputas las candidaturas para las elecciones de representantes parlamentarios y municipales. La situación se complicaba aún más debido a las extremadamente móviles fronteras políticas, que permitían la existencia de liberales (de distintas tendencias) tanto en el gobierno como en la oposición, y el paso fluido, derivado de la adhesión a programas y principios, de personajes y sectores desde un bando hacia otro sin mayores problemas.

La "unión sagrada" antibalmacedista, que aún había operado durante el gobierno de Jorge Montt (1891-1896), dejó de existir durante el período presidencial de Federico Errázuriz (1896-1901). Se acentuó el personalismo o caudillismo, de modo tal que los parlamentarios obedecieron cada vez más a sus lealtades personales y menos a sus colectividades. También se arraigó la percepción de la administración pública y municipal como un botín de los partidos y comenzó lo que el historiador Gonzalo Vial calificó como

“distorsión de los mecanismos 'fiscalizadores' que detentaba el Congreso, empleándose para fines baladíes las interpelaciones, el retardo del presupuesto, etc., llegándose a resolver políticamente $-\mathrm{y}$ hasta por acuerdos previos- las calificaciones de los mandatos parlamentarios, en las cuales la Cámara respectiva debía actuar como juez"177.

En ese contexto se dio la batalla por las elecciones generales (parlamentarias y municipales) de marzo de 1897. El 18 de septiembre de 1896, cuando recién habían transcurrido quince días de la proclamación por el Congreso Pleno de Federico Errázuriz Echaurren como nuevo Presidente de la República, en representación de la "Coalición" (bloque conformado por una híbrida alianza entre algunos sectores liberales y el Partido Conservador), el directorio de la Alianza Liberal en el que participaban representantes del PD sacó un manifiesto planteando que la disyuntiva política del momento, que debía zanjar el Presidente de la República, era si se trataría de un gobierno liberal o un gobierno conservador ${ }^{178}$.

El PD, bajo la conducción de Malaquías Concha, se alineó firmemente tras la opción descrita por la Alianza Liberal, pero teniendo conciencia del estado inorgánico de ese conglomerado. Y ante su falta de preparación para la contienda electoral, en el manifiesto de octubre el Directorio General recomendó a sus militantes disponerse como si fueran a concurrir solos a las elecciones. Si la Alianza se organizaba oportuna y convenientemente, se habrían acrecentado las fuerzas con que participaría el PD. Si por el contrario, cada grupo emprendía su propia campaña, los demócratas estarían en condiciones de llevar al Congreso Nacional el mayor número de repre-

176 Estos sufragios se tradujeron en diez electores para Presidente de la República en 1896.

177 Vial, op. cit., II:228.

178 "Manifiesto. El Directorio de la Alianza Liberal a sus correlijionarios", El Hijo del Pueblo, San Felipe, 20 de septiembre de 1896. Firmaron en representación del Partido Democrático: Alejandro Bustamante, Malaquías Concha, Ángel Guarello, Moisés González y Francisco Landa Z. 
sentantes, absteniéndose de todo compromiso o unión parcial de fuerzas que no obedeciera a un pacto general y uniforme de partido ${ }^{179}$.

Para los demócratas, la alianza con otras tendencias liberales debía darse en pie de igualdad y, tal como explicaban los dirigentes de la agrupación de San Felipe, "sin refundir a los partidos aliados sino que cada cual conservando la integridad de su programa" y teniendo como objetivo la constitución de un gobierno sólido y estable de tendencia liberal y democrática ${ }^{180}$. En la primera sesión de los comités de la Alianza Liberal celebrados en diciembre de 1896, uno de los representantes demócratas propuso la organización permanente del conglomerado como una federación de los cuatro partidos que la constituían y dotada de una dirección propia compuesta por doce miembros elegidos en número igual por cada uno de las colectividades aliadas. Dicho organismo -que no se sobrepondría a las direcciones de cada partido, por cuanto estos mantendrían su plena independencia y autonomía- sería el encargado de administrar los intereses comunes del conglomerado, entendiendo como tales una amplia gama de materias que abarcaban desde las cuestiones constitucionales hasta un significativo número de leyes, como las relativas a la constitución del estado civil de las personas, el mantenimiento de la laicidad de las instituciones, instrucción primaria, protección a la industria nacional, etc., pasando por las cuestiones relativas a las elecciones generales y las funciones gubernamentales en su dirección o fiscalización $^{181}$.

Estas proposiciones no fueron acogidas por sus destinatarios. En realidad, ni siquiera fueron objeto de una discusión seria, porque en las comisiones de la Alianza Liberal se produjeron importantes desacuerdos acerca de la representación que el PD debía tener en las listas electorales. En diciembre sus aliados cuestionaron públicamente la aspiración de los demócratas de llevar ocho candidatos a diputados, manifestando su intención de concederles solo cuatro candidaturas. Los demócratas rebajaron sus pretensiones a siete postulantes a diputados y renunciaron a su aspiración a presentar un candidato al Senado, además de otras concesiones en ciertos niveles locales ${ }^{182}$. Solo en ciertas localidades, como fue el caso de Nueva Imperial, se constituyeron organismos conjuntos de los partidos de la Alianza, incluyendo al Demócrata, a fin de prorratear las candidaturas y organizar la campaña ${ }^{183}$.

Ante la falta de respuesta de sus aliados, el Directorio General demócrata acordó en los primeros días de enero de 1897 instruir las bases del partido para que proclamaran rápidamente candidatos propios a municipales y parlamentarios. En el caso de los senadores y diputados, decía la circular de la directiva demócrata, debía procederse a su designación, cualesquiera que fuesen las fuerzas con que contaran las

179 "Manifiesto del Directorio General a las agrupaciones del Partido Democrático", op. cit.

180 "La próxima Convención democrática", El Hijo del Pueblo, San Felipe, 14 de noviembre de 1896. Destacado en el original.

181 "Gran pensamiento político. La federación permanente de los partidos liberales", El Hijo del Pueblo, San Felipe, 19 de diciembre de 1896.

182 "En desacuerdo", El Trabajo, Concepción, 4 de enero de 1897; "La actitud de la Alianza Liberal con el Partido Democrático", El Hijo del Pueblo, San Felipe, 10 de enero de 1897.

183 [Editorial] y “Actualidad política”, La Democracia, Nueva Imperial, 20 de diciembre de 1896. 
agrupaciones partidarias. Respecto de las elecciones municipales, se recomendaba "pesar muy exactamente sus propios elementos para procurarse una representación local segura, que no se halle expuesta a los vaivenes de la lucha"184. Y para evitar las confusiones que esta fórmula podía dejar respecto de posibles alianzas en el ámbito local, se advirtió enérgicamente que el directorio prohibía “de la manera más absoluta y terminante todo arreglo o concurso prestado por las agrupaciones a candidatos extraños al partido". Por ningún motivo las agrupaciones podían considerarse autorizadas para pactar arreglos locales, so pena de ser separados del partido quienes contrariando estas instrucciones apoyaran a "candidatos extraños"185.

Puesto que hasta ese momento no existía acuerdo con los partidos escogidos como aliados, sin perjuicio de lo que pudiera decidirse más adelante, el Directorio General demócrata ordenó a sus agrupaciones retirarse de los comités locales de la Alianza Liberal y obrar como si debieran ir "completamente solos a las urnas"186.

La extrema volatilidad y fragmentación del cuadro político y el frecuente trasvasije de grupos y fracciones liberales de una alianza a otra impidieron el total aislamiento del PD. Maniobrando en estas turbulentas aguas, a fines de enero el Directorio General del partido logró constituir una "Alianza Liberal” junto a una fracción radical y a una fracción "liberal-aliancista", con exclusión de los exaliados balmacedistas o liberales democráticos, que eran quienes con mayor virulencia se habían opuesto a las aspiraciones demócratas ${ }^{187}$. De este modo, el PD enfrentó las elecciones de marzo con una alianza reducida y quebrando lanzas no solo contra el tradicional enemigo conservador, sino también contra aquellos sectores del liberalismo que habían abandonado la antigua Alianza Liberal en pos de un botín electoral y de cargos públicos más suculentos.

El PD apoyó las opciones senatoriales de las otras fuerzas de la Alianza Liberal en las cinco provincias que renovaban sus representantes y presentó como candidatos a diputados dentro del mismo conglomerado a Ángel Guarello (que postuló a la reelección) por Valparaíso, Artemio Gutiérrez por Santiago, Malaquías Concha por Concepción, Francisco Cobo por Laja, Nacimiento y Mulchén y Alejandro Bustamante por Angol, Collipulli, Traiguén y Mariluan ${ }^{188}$. Pero su opción aliancista chocó en algunos casos con las reticencias de algunos militantes o con la ambición que llevó a algunos demócratas a intentar levantar candidaturas sobre la base de otras alianzas que se ofrecían en el gelatinoso cuadro político nacional. Por ese motivo, la agru-

184 "Circular a las agrupaciones del Partido Democrático", El Hijo del Pueblo, San Felipe, 10 de enero de 1897.

185 Idem.

186 Idem.

187 "Manifiesto de la Alianza Liberal. A sus correligionarios y al país", El Hijo del Pueblo, San Felipe, 30 de enero de 1897. Firman este documento por el Partido Democrático: Malaquías Concha, Ángel Guarello y Francisco Landa. Entre los "liberales aliancistas" destaca Eduardo Matte y entre los radicales Guillermo Matta y Abraham Köning.

188 "Candidatos del Partido Democrático para diputados", El Hijo del Pueblo, San Felipe, 13 de febrero de 1897; "Alianza Liberal. Circular de la Junta Directiva”, El Hijo del Pueblo, San Felipe, 20 de febrero de 1897. Firman este documento, en tanto representantes demócratas, Malaquías Concha, Ángel Guarello, Artemio Gutiérrez y Francisco Landa. 
pación de Linares fue disuelta y reorganizada por el Directorio General, y un grupo de sus integrantes fueron marginados por haberse adelantado a proclamar "candidatos extraños" al partido. Las agrupaciones departamentales quedaron en libertad de resolver el tema de las candidaturas "en proporción a las fuerzas de cada partido" 189.

En las votaciones del 7 de marzo resultaron elegidos diputados los demócratas Artemio Gutiérrez (por Santiago) y Ángel Guarello (reelegido por Valparaíso). En numerosos municipios el PD eligió un apreciable número de concejales. En Valparaíso, cinco de sus miembros alcanzaron el triunfo, lo que les permitió ungir como primer alcalde a Juan Bautista Bustos, redactor del diario El Pueblo, y constituir un pacto de gobierno comunal con un par de regidores balmacedistas que se separaron de aquellos representantes de su partido que habían concluido una alianza con los concejales conservadores ${ }^{190}$.

Según ciertos cálculos, en marzo de 1897 los electores enviaron a la Cámara de Diputados 26 representantes de la Alianza Liberal contra una abrumadora mayoría de 68 de la coalición gobernante ${ }^{191}$. Pero estas cifras eran engañosas, ya que las fronteras entre la Alianza y la Coalición tendieron a borrarse casi por completo luego de los comicios. Los balmacedistas, por ejemplo, que habían registrado un crecimiento significativo tanto en el número de diputados como de senadores, en teoría se habían sumado al gobierno, o sea, a la Coalición, pero la posición de muchos de sus parlamentarios era poco clara. Igualmente poco transparente había sido la actitud de los liberales doctrinarios y del sector del radicalismo, que se había aliado con los demócratas en las elecciones recién pasadas.

\section{LOS DEMÓCRATAS DE LLENO EN LA POLÍTICA PARLAMENTARIA}

Cuando en mayo llegó el momento de elegir las mesas directivas del Parlamento, los dos diputados demócratas tomaron revancha sobre sus exaliados de la víspera, acusándolos de no haber respetado fielmente los compromisos electorales, por lo que votaron para esos cargos por liberales de gobierno, o sea, coalicionistas. La voltereta no fue fácil. El Directorio General demócrata debió ejercer una fuerte presión sobre sus parlamentarios para que adoptaran una posición contra natura. En el caso del reelegido diputado Ángel Guarello, solo una orden escrita de la directiva nacional de "la Democracia" y de la Agrupación de Valparaíso en la cual militaba lograron vencer su resistencia. Por disciplina, y luego de expresar "vivas protestas", Guarello apoyó a regañadientes a los candidatos a la mesa de la Cámara y a consejeros de Es-

189 "Circular. El Directorio General al Partido Democrático", El Hijo del Pueblo, San Felipe, 6 de febrero de 1897.

190 Poco después de la elección municipal, la alianza entre los conservadores y la mayoría de los concejales balmacedistas despojó a Bustos de su cargo de alcalde y desató una dura campaña contra los demás representantes demócratas. Illanes, "El fruto prohibido de la guerra civil...", op. cit., 480-494.

191 De Petris, op. cit., 21. 
tado que presentaba la Coalición, para que, a cambio de este apoyo, los coalicionistas respetaran la diputación recién obtenida por Malaquías Concha ${ }^{192}$.

¿Se había pasado el PD a la Coalición de la cual formaban parte los conservadores ultramontanos? El Directorio General demócrata lo negó tajantemente en un comunicado publicado el 23 de mayo. El pacto concluido con radicales y liberales doctrinarios -señaló- no había sido honrado por dichos aliados y, como si fuera poco, en aquellos pueblos donde habían triunfado candidatos del $\mathrm{PD}$, el fraude y la falsificación les había arrebatado su victoria. ¿Qué hacer en esas circunstancias?:

\begin{abstract}
"No podíamos decorosamente, sin abdicar nuestra dignidad y la personalidad de nuestro partido, continuar una alianza rota por la mala fe de nuestros aliados, mucho menos constituirnos en ciegos instrumentos de su política exclusivista, sectaria y enemiga de los bien entendidos intereses del pueblo que representa el Partido Democrático.

Así han debido entenderlo en su propia conciencia, pues no han intentado acuerdo alguno antes de la reunión del Congreso, ni siquiera tuvieron la cortesía de comunicar al directorio o a los diputados demócratas su resolución de votar para presidente de la Cámara por el diputado que designaron sin consultarnos.

Combatidos por radicales y balmacedistas que intentan falsear la voluntad popular, arrojando del parlamento a nuestros propios correligionarios, no hemos trepidado un solo instante en resguardar los intereses del partido, defendiendo la investidura de los diputados demócratas para lo cual contribuyeron los diputados en ejercicio, dando sus votos para presidente a un distinguido liberal que nos daba plenas garantías de imparcialidad" ${ }^{193}$.
\end{abstract}

Ante la viciosa práctica inaugurada en la República Parlamentaria de dejar en las manos del propio Congreso Nacional la "calificación" de las elecciones, o sea, validar o anular sus resultados en función de intereses y acuerdos políticos de mayoría, el PD había optado por resguardar las diputaciones obtenidas, estableciendo alianzas tácticas con los liberales de gobierno, sus adversarios en la elección de marzo. Por ello el Directorio General demócrata había acordado seguir una política desligada de cualquier compromiso con partidos que se ocultaran tras ideas para defender intereses egoístas, y apoyaría todo tipo de acciones que beneficiaran al pueblo, que tendieran a superar la crisis económica y a proteger el trabajo y la industria nacional. En torno a este punto dejaba entreabierta la posibilidad de acuerdos con la coalición de gobierno, lo que sus exaliados ya le reprochaban como una traición. Si, como parecía, el Presidente de la República se empeñaría formalmente en proteger el trabajo y la industria nacional, no cabía sino apoyarlo. La orden presidencial para fabricar en el país todo el material rodante de los ferrocarriles y la sustitución de las importaciones del costoso mobiliario y decoración del Palacio de la Moneda por productos

192 Ángel Guarello, “A mis correligionarios políticos”, El Mercurio de Valparaíso, Valparaíso, 29 de marzo de 1901. Guarello entregó antecedentes sobre lo ocurrido en 1897, al ser proclamado nuevamente candidato a diputado en 1901. En esa oportunidad evocó su trayectoria política, aludiendo a la "única excepción" en que se había visto obligado a aportar su voto para apoyar candidatos de la Coalición.

193 "Circular. El Partido Democrático a las agrupaciones departamentales", El Ferrocarril, Santiago, 23 de mayo de 1897. 
nacionales eran medidas positivamente valoradas por los dirigentes del partido, como signos de una política que impulsaría el trabajo nacional ${ }^{194}$.

La táctica escogida permitió "salvar" las diputaciones de Guarello y Gutiérrez, no así la de Malaquías Concha por Concepción, circunscripción en la que se produjo una áspera disputa entre radicales y demócratas, que se acusaron mutuamente de fraudes, definiéndose la situación recién en diciembre de 1897, cuando la Cámara de Diputados en un informe de mayoría determinó el triunfo del candidato radical ${ }^{195}$.

El PD entraba de lleno en el juego de las prácticas del "parlamentarismo a la chilena" de la época. Si bien sus principios seguían siendo los mismos y las maniobras se justificaban como una defensa de las posiciones conquistadas, en la práctica los demócratas, representados por su Directorio General, quedaban -a su pesar- como una pequeña fuerza expuesta a ser conquistada, seducida, sumada, cooptada o avasallada según las circunstancias, por los distintos partidos o banderías que ocupaban las principales posiciones en el juego político. El cohecho, el tráfico de influencias, el maridaje entre política y negocios, la "calificación" de las elecciones por los propios congresales, el carácter espurio y la volubilidad de las alianzas, todo parecía conspirar contra la permanencia impoluta de una organización política popular que se proponía actuar al interior de un sistema político oligárquico con el fin de democratizarlo y ponerlo al servicio de la mayoría popular del país.

La acentuación de la propensión del partido a asumir los métodos que tradicionalmente habían caracterizado a las otras fuerzas políticas se combinó con una creciente tendencia a otorgar al Directorio General amplias atribuciones para definir el camino a seguir, tal como se manifestó en las convenciones de Valparaíso (1895) y Concepción $(1897)^{196}$. La molestia que estas prácticas comenzaron a generar entre ciertos segmentos de los militantes de base y dirigentes medios del partido fue una suerte de premonición del cisma que poco después se produciría en las filas de "la Democracia”. Estas contradicciones y fricciones se derivaban directamente de la opción adoptada por el PD de inscribirse en el juego político representativo, debiendo pagar por ello el precio de constantes tensiones y fraccionamientos internos. La válvula de escape -que con el tiempo tendería a tornarse ritual y por ende totalmente inocuaera la afirmación de la independencia y autonomía del partido, dejando casi siempre un amplio margen de acción para que la directiva nacional o las agrupaciones locales establecieran alianzas que ponían en entredicho práctico dicha política.

De esta manera, en la Convención Democrática efectuada en Santiago en noviembre de 1897, los delegados acordaron mantener la independencia del partido y

194 Idem.

195 De Petris, op. cit., 22.

196 "Santiago. Convención democrática de anoche", El Mercurio de Valparaíso, Valparaíso, 24 de noviembre de 1897; Programa i Reglamento del Partido Democrático. Aprobados por la Convención de Santiago en 14 de julio de 1889, con la reforma hecha al Reglamento por la Convención celebrada en Valparaíso el 14 de julio de 1895 i el 14 de julio del 97 en Concepción, Santiago, Imprenta i Librería del Centro Editorial La Prensa, 1899. Una crítica desde las propias filas demócratas a las "facultades tan omnímodas" otorgadas al Directorio General por esas convenciones se encuentra en: "La próxima Convención. Reformas que se imponen", La Democracia, Santiago, 21 de mayo de 1899. 
combatir todo régimen de coalición, esto es, de alianza de fuerzas liberales con el Partido Conservador, y, por tanto, situarse en la oposición al gobierno del presidente Errázuriz. Un punto central de la estrategia definida fue la agitación patriótica y la exigencia de "mano dura" al gobierno, a raíz de los conflictos limítrofes que oponían Chile a Argentina ${ }^{197}$.

Siguiendo estos acuerdos, el PD se lanzó de lleno en una campaña de agitación nacionalista, por medio de meetings que comenzaron simultáneamente el 23 de enero de 1898 en Santiago, San Felipe, Rancagua, Talca, Talcahuano, Temuco y otras ciudades ${ }^{198}$. Al término de la manifestación celebrada en la capital, los delegados demócratas pusieron en manos del Presidente de la República las conclusiones que expresaban la necesidad de "mantener incólume la integridad del territorio nacional, dentro del cumplimiento leal y honrado de los tratados vigentes". La respuesta del jefe de Estado fue tranquilizadora: las relaciones internacionales del país, les dijo, se mantenían en pie de paz y armonía, no había razones de alarma y los asuntos pendientes con algunas naciones estaban siendo sometidos a pactos a fin de solucionar pacíficamente las divergencias o dificultades que pudieran surgir ${ }^{199}$.

¿Cuál era el sentido político de la campaña patriótica de los demócratas? Sin duda su partido compartía el sentimiento nacionalista ampliamente prevaleciente en Chile, exacerbado por las dificultades en las relaciones internacionales con los países vecinos. En este sentido, no hacía sino recoger una preocupación de vastos sectores de la opinión pública. Al mismo tiempo, buscaba recuperar el espacio perdido en la agitación social, relegado a un lugar secundario por los propios demócratas, debido a su creciente preocupación por las cuestiones electorales. No está de más recordar que, desde el ingreso del PD a la Alianza Liberal, habían surgido a su izquierda otras expresiones políticas populares -aún vagamente socializantes o anarquizantes- que pretendían disputarle su clientela, especialmente a través de las luchas sociales y la acción callejera ${ }^{200}$.

Pero la cruzada patriótica no representó una inflexión decisiva en la orientación del partido. El tiempo de las grandes campañas de masas de los años $1888-1890^{201}$ ya era lejano y las preocupaciones electorales siguieron ocupando el centro de atención de sus principales dirigentes. A decir verdad, las motivaciones "electoralistas" alcanzaban al conjunto del partido, involucrando a la inmensa mayoría de sus militantes. Hacia los últimos años del siglo, aún se debatía en las agrupaciones demócratas si el partido debía mantener de manera inflexible su tantas veces proclamada independencia política o si, por el contrario, preservando su perfil y libertad de acción, debía buscar alianzas con las fuerzas liberales para enfrentar al conservadurismo y evitar que sus mandatos de representación popular fueran escamoteados por el cohecho y las "calificaciones" parlamentarias.

197 De Petris, op. cit., 22.

198 AHN, Fondo Ministerio del Interior (en adelante FMI), fjs. 295-306 v.; "El meeting del domingo", El Pueblo, Valparaíso, 20 de enero de 1898.

199 "El meeting del Domingo", El Ferrocarril, Santiago, 25 de enero de 1898.

200 Grez, Los anarquistas..., op. cit., passim.

201 Grez, De la "regeneración del pueblo”..., op. cit., 672-698. 
Las características y las prácticas del sistema político de la época y, muy especialmente, la gran elasticidad, fragilidad y poca durabilidad de los sistemas de alianza, repercutían negativamente al interior del PD. La militancia no solo enfrentaba el dilema de la independencia partidaria versus una política de alianzas con otras fuerzas liberales, sino que también sufría las tensiones que se derivaban de distintas opciones, toda vez que se optaba por llegar a acuerdos y pactos en el terreno electoral. En 1897, por ejemplo, con motivo de las elecciones municipales, la agrupación de Iquique sufrió una división entre "aliancistas" y "coalicionistas", que se tradujo en la presentación de listas demócratas separadas. Juan de Dios Arellano (dueño de un salón de billar) aprovechó el apoyo de radicales y balmacedistas "aliancistas" para obtener la séptima mayoría (1.163 sufragios), llegando de esta manera a ser el primer representante municipal demócrata iquiqueño elegido explícitamente en su calidad de tal. Los demócratas "coalicionistas" Santiago del Campo (médico) y Federico González (mueblista) fueron derrotados. Pero más suerte tuvo el viejo y prestigiado dirigente demócrata Juan Segundo Leiva, quien se presentó como "independiente" (probablemente un subterfugio) y con el apoyo de las organizaciones obreras logró el primer lugar en la elección popular (1.503 sufragios), aunque semanas más tarde las maniobras de los demás políticos lo relegaron al sexto puesto entre los regidores ${ }^{202}$. En otras ciudades, como en Talcahuano hacia fines de 1898 y principios de 1899, los demócratas eran víctimas de las divisiones producidas, según algunas versiones, por la injerencia de conservadores y radicales que intentaban hacer obra de zapa y conquistar prosélitos ${ }^{203}$.

De este modo, en 1899 el PD se encontraba oficialmente en oposición al gobierno de Errázuriz, según lo acordado el 12 de enero de ese año por su Directorio General, en el sentido de "hacer política de franca y abierta oposición a toda influencia conservadora" y "hacer política de fiscalización de todo gobierno liberal" 204 . Pero la disyuntiva de escoger "entre lo malo y lo peor" -como se leía en un editorial de La Democracia a mediados de abril ${ }^{205}$ - llevaba inevitablemente a los demócratas, a pesar de sus declaraciones de no volver jamás a ingresar a otra Alianza Liberal ${ }^{206}$, a concluir pactos o alianzas con los liberales opuestos a los gobiernos de coalición. Por ello, a fines de ese mes, el núcleo santiaguino que editaba La Democracia (Florentino Vivaceta, Honorato Farías, Luis Emilio Recabarren e Isaías González, entre otros) matizó su enérgico rechazo a volver a formar parte de la Alianza Liberal, declarando que ese conglomerado no debía ver en el PD una "rémora para sus acciones", además de reconocer que dicho bloque se formaría inevitablemente porque así lo imponía la

202 Pinto Vallejos, “¿Cuestión social o cuestión política?...”, op. cit., 275-277.

203 A. de L., "La semana", La Democracia, Santiago, 12 de febrero de 1899; "La agrupación de Talcahuano", La Democracia, Santiago, 19 de febrero de 1899.

204 "Actitud de nuestro partido", La Democracia, Santiago, 29 de enero de 1899.

205 "Entre lo malo i lo peor", La Democracia, Santiago, 16 de abril de 1899.

206 "Crónica. Rectificamos", La Democracia, Santiago, 16 de abril de 1899; "La unificación liberal i el Partido Democrático (De La Justicia de Talcahuano)", La Democracia, Santiago, 20 de abril de 1899. 
situación del país ${ }^{207}$. No obstante, en otro artículo de la misma edición, estos demócratas precisaron que ante un gobierno liberal actuarían como meros fiscalizadores ${ }^{208}$.

Los demócratas enfrentaban una delicadísima disyuntiva. Sumar sus fuerzas nuevamente a la Alianza Liberal impediría probablemente el triunfo del aborrecido clericalismo, pero significaba exponerse a que una vez más sus aliados liberales de distintos matices se sirvieran de sus votos, no respetaran fielmente los pactos y continuaran aplicando una política denostada en tantas ocasiones por "la Democracia". ¿Qué hacer? Si numerosos demócratas desechaban la reconstitución pura y simple de la Alianza Liberal, ¿qué alternativa quedaba? ¿Levantar una política de autonomía absoluta con el riesgo de allanar el camino de la coalición conservadora-monttvarista al gobierno? El debate se acentuó en vísperas de la Convención Extraordinaria del partido. Entre las dos opciones extremas -autonomía absoluta o ingreso irrestricto a la Alianza Liberal-, Víctor Soto Román, antiguo militante demócrata que poco después protagonizaría un corto pero destacado y controvertido paso por las filas anarquistas $^{209}$, levantó una posición intermedia. Luego de describir las traiciones de sus antiguos aliados y de atribuir la responsabilidad del repunte conservador a los gobiernos liberales, Soto Román criticó a aquellos demócratas que proponían la integración a la Alianza Liberal y propuso una especie de tercera vía:

"Sin embargo, la autonomía completa del partido no es posible; la autonomía nos dará representación en las agrupaciones grandes, pero se perderá miserablemente en alguna de las chicas; además con la autonomía absoluta, se arma el brazo de todos los partidos burgueses para que obstruyan el triunfo de nuestros representantes a los cuerpos políticos. Ni alianzas generales ni autonomía completa. Entonces: ¿qué política seguiremos en la próxima campaña? La política de guerrilla dejando a las agrupaciones pequeñas en la libertad de efectuar cambios de fuerzas según sus necesidades; para el efecto de elegir los municipales en caso de no poder presentar candidatos a diputados" ${ }^{210}$.

Pocos días antes de la apertura de la Convención Extraordinaria del PD fijada para el 28 de mayo $^{211}$, el sector liberal-democrático o balmacedista, presidido por Claudio Vicuña, dirigió al presidente demócrata Artemio Gutiérrez una invitación para renovar o reconstituir la Alianza Liberal. Una parte de los radicales se sumó a la iniciativa. La Convención Demócrata reunida en Santiago acordó entonces combatir todo gobierno de coalición y propender, "por todos los medios", al alcance de sus diputados a la formación de un "gabinete netamente liberal", que diera garantías de respeto a la libertad electoral y que dictara medidas tendientes a proteger la industria nacional. El Directorio General fue autorizado nuevamente para pactar alianzas o uniones locales con los demás partidos afines, con el objeto de asegurar al PD su representación municipal y parlamentaria. Solo quedaban excluidos de esta política de

\footnotetext{
207 "La Alianza Liberal i el Partido Democrático", La Democracia, Santiago, 23 de abril de 1899.

208 "Rachas amargas", La Democracia, Santiago, 23 de abril de 1899.

209 Grez, Los anarquistas..., op. cit., 200-205.

210 Víctor Soto Román, “Alianza Liberal”, La Democracia, Santiago, 14 de mayo de 1899.

211 "Circular a las Agrupaciones del Partido Democrático", La Democracia, Santiago, 27 de abril de 1899.
} 
alianzas el Partido Conservador y aquellos candidatos liberales que se opusieran al proteccionismo económico ${ }^{212}$.

Así, en la perspectiva de las elecciones marzo de 1900, a fin de hacer frente a la creciente influencia conservadora-monttvarista y, sobre todo, para atajar a Pedro Montt, seguro candidato de esa coalición, los demócratas dieron nuevamente su apoyo para la reconstitución de la Alianza Liberal. Cinco partidos -Radical, Liberal Democrático (sector dirigido por Claudio Vicuña), Liberal Doctrinario, Liberal y Demócrata- unieron sus fuerzas tras el objetivo de oponerse a cualquier tipo de gobierno de "coalición directa o indirecta" y propender a la implantación de un gobierno "netamente liberal". Más aún, movidos por el entusiasmo, los representantes del sector Liberal Doctrinario propusieron la unificación total en un solo partido de las organizaciones en que se encontraba dividido el antiguo Partido Liberal ${ }^{213}$. Como la fórmula propuesta no alcanzaba al PD, cuando se reunieron los comités de los partidos aliancistas para discutir la proposición de fusión total en una misma organización y con un mismo programa, los demócratas no estuvieron representados ${ }^{214}$. Pero ello no impedía su participación en la Alianza Liberal.

La nueva versión aliancista tenía, al igual que las anteriores, debilidades congénitas, derivadas de los vicios que caracterizaban el funcionamiento de los partidos políticos bajo la República Parlamentaria. La inestabilidad, fragmentación de las alianzas y de los partidos que las componían eran fenómenos crónicos que impedían la estructuración de un cuadro político medianamente estable. Así, apenas transcurrido un mes de la reconstitución de la flamante Alianza Liberal, un sector de ella dio su voto de confianza a un ministerio que no alcanzó los dos meses de vida (28 de junio al 19 de agosto $)^{215}$.

Con todo, hacia fines de octubre la Alianza Liberal (o lo que quedó de ella) determinó los cupos para candidaturas parlamentarias que corresponderían a cada uno de sus partidos, acordándose seis de un total de sesenta y un candidatos a diputados a los demócratas ${ }^{216}$, lo que estaba lejos de satisfacer sus aspiraciones.

\section{CONCLusión}

Entre 1891 y 1896 la estrategia política del PD chileno sufrió una profunda evolución que lo llevó a transitar, desde una postura de "autonomía absoluta" respecto de las demás fuerzas políticas presentes en el juego parlamentarista hacia su integración formal en la Alianza Liberal. Esta marcha estuvo plagada de dificultades, contradicciones y luchas en el seno del PD y entre este y sus aliados liberales. El

212 De Petris, op. cit., 23 y 24.

213 "Noticias de Santiago. Alianza Liberal”, El Mercurio de Valparaíso, Valparaíso, 1 de junio de 1899.

214 "Noticias de Santiago. Alianza Liberal", El Mercurio de Valparaíso, Valparaíso, 12 de junio de 1899.

215 "Liquidación de la Alianza Liberal”, El Mercurio de Valparaíso, Valparaíso, 24 de agosto de 1899.

216 "Noticias de Santiago. Candidaturas de la alianza liberal", El Mercurio de Valparaíso, Valparaíso, 28 de octubre de 1899. Según esta información de prensa, los demócratas no obtuvieron ningún cupo para candidatos a senadores, conviniéndose que en la provincia de Santiago cada partido trabajaría por su cuenta. 
PD debió resolver primero -básicamente durante la primera mitad de esa década- el problema de su unidad interna, seriamente afectada por la guerra civil de 1891. Aparte las divisiones que había provocado en "la Democracia" dicho conflicto, nuevas disyuntivas -como la de mantener su "autonomía absoluta" o desarrollar una política de alianzas con las otras fuerzas de la "gran familia liberal"- tensionaron al joven partido popular, hasta el punto de provocar, en 1896, el desprendimiento de algunos núcleos militantes que desde su izquierda se aferraban a la política de independencia y "autonomía absoluta" anunciada recurrentemente por los demócratas.

Venciendo muchas resistencias internas, Malaquías Concha, Artemio Gutiérrez y otros dirigentes que optaron por una estrategia de "realismo político" destinada a insertar al PD en el sistema parlamentarista, obteniendo representación parlamentaria y municipal, lograron imponer el ingreso de su colectividad a la Alianza Liberal. Los principales factores que pesaron en el triunfo de esta opción fueron el sentimiento anticonservador y anticlerical imperante en la militancia demócrata -que actuaba como una poderosa fuerza en pos de la alianza con distintas tendencias y partidos del arco liberal- y la necesidad del PD de "defender" las diputaciones alcanzadas en el contexto de la nociva práctica política imperante en aquella época, que permitía a la Cámara de Diputados "calificar" las elecciones, esto es, ratificar o alterar el veredicto de las urnas, en función de espurios acuerdos partidarios.

El ingreso del PD a la Alianza Liberal y al juego parlamentarista conllevó inevitablemente el inicio de un germen de corrupción política que, años más tarde, produciría una división duradera entre los sus integrantes. El surgimiento de dos tendencias que luego se constituirían en fracciones con carácter permanente -"reglamentarios" y "doctrinarios"- encontró en las opciones tomadas a mediados de los 90 su punto de partida más remoto. Desde entonces la puerta estaba abierta para que el sector hegemónico, liderado por Concha, so pretexto de defender los intereses del partido, incurriera en las alianzas, pactos y compromisos más variados y alejados del ethos autonomista proclamado por "la Democracia". Por ello no fue extraño que, hacia fines del período estudiado, estos dirigentes impusieran a sus bases y parlamentarios la convergencia táctica con liberales coalicionistas (esto es, aliados de los conservadores) y que, a pesar de numerosas pruebas de deslealtad de sus aliados, el PD estuviera siempre dispuesto a reconstituir la Alianza Liberal. El complemento de esta "cooptación" del partido, que en el momento de su fundación se había propuesto luchar por la "emancipación económica, política y social del pueblo de Chile", era la tendencia cada vez más marcada a entregar a su Directorio General atribuciones más amplias para definir, por sí y ante sí, las políticas a seguir. Y aunque periódicamente las convenciones demócratas afirmaban como un rito consagrado su independencia y “autonomía absoluta”, esta ya era cosa del pasado. De este modo, al expirar el siglo estaban todas las condiciones para que nuevas tendencias contestatarias se afirmaran en su seno, buscando retomar su definición política original. 